\title{
Which Religions Still Affect Schooling? A Study of 143 Countries
}

\author{
Horst Feldmann \\ Department of Economics, University of Bath, Bath, UK \\ h.feldmann@bath.ac.uk
}

\begin{abstract}
This paper studies which world religions have exerted a contemporary influence on the extent of secondary schooling at the national level in the recent past. Using data on 143 countries and the period 1973 to 2012, it finds that both Hinduism and Judaism have a large positive effect, particularly among females. The group of other Eastern religions (which covers comparatively small religions, notably Confucianism) also has a positive effect, though it is slightly smaller, especially among girls. Islam has a negative effect, which is larger among females than among males. Neither Buddhism nor the three branches of Christianity - Eastern Orthodoxy, Roman Catholicism and Protestantism have any statistically significant effect. The results are robust to numerous controls and variations in specification.
\end{abstract}

\section{Keywords}

education - religion - schooling

\section{$1 \quad$ Introduction and Background}

Using data on 143 countries, this paper econometrically studies which world religions have affected the extent of secondary schooling at the national level in the recent past - specifically, over the period from 1973 to 2012 . It focuses not on any historical legacy world religions might have left in today's education but on their contemporary influence. Traditionally, education has played a key role in most world religions. These religions have shaped education since ancient times. Well-known examples are Confucianism, Judaism and 
Protestantism. Confucius considered education to be the most important task in society. ${ }^{1}$ His teaching focused on moral principles and traditional knowledge. His core moral principles were (To 1993, Sun-keung Pang 2011): ren, which signifies humaneness, supreme moral achievement and excellence in character; chung, which means doing one's best in discharging one's duties; $y i$, which can be translated as moral rightness and appropriateness; and $l i$, which represents the norms, etiquettes and protocols in both daily and institutional life. Confucius' main intention was to educate individuals of outstanding virtue who would assist the emperor in governing with integrity. His teaching of traditional knowledge aimed at maintaining cultural continuity and social stability (Ornstein et al. 2013). Apart from ethics, instruction included reading, writing, arithmetic, music, language, politics and literature (To 1993). Confucius made his students work hard and examined them rigorously. He thought that schooling should be made available to all young people who were motivated to learn, no matter what their background or status (Lee 2000). Indeed, his students came from the lowest as well as from the highest levels of society (Ho 1959). In this way, he founded a long tradition of education in China as well as in other East Asian countries such as Japan and Korea (To 1993, Yang 1993, Lee 2000). However, because women could not hold civil service positions, education for girls remained very limited for centuries (Kelleher 1987).

Jews are often known as "The People of the Book" (Miller et al. 2011). The Torah is replete with dicta to "teach your children diligently" about Jewish mores and history (Zeldin 2011). After the Romans had crushed the Jews' Great Revolt in $70 \mathrm{AD}$, a formal school system was initiated (Botticini and Eckstein 2012). In face of exile and loss of independence, education was charged with the responsibility for the continued existence of Judaism and the unity of the Jewish people (Iram 1993). Schooling of boys was made compulsory (Brickman 2008). Until the late 18th century, girls received no formal education and the curriculum was strictly religious (Carmody 1987, King 1987). Secular subjects were mostly excluded. Jewish communities ran their own schools, which were often attached to synagogues. Teaching was in Jewish languages only (Alexander and Glick 2003).

From the beginning of the Reformation, Protestantism has stressed the need for education too. Its founder, Martin Luther, demanded compulsory elementary schooling for both boys and girls of all social classes (Bowen 1975, Boyd

1 Although it does not have gods or deities, Confucianism has achieved a status equal to that of major religions in human history, due to its elaborate system of ideals and moral codes (To 1993, Sun 2013). 
and King 1975). The best students should progress to secondary school. Schools should be run by the state. Luther advocated not only religious but also secular and vocational education (Harran 1997). In his view, children needed not only to be enabled to read the Bible, they also needed to be prepared to become orderly and productive citizens (Bowen 1975). From the 16th century throughout the Protestant states of Germany as well as in other countries that had broken away from Rome, numerous schools were founded on the model developed by Luther and his co-reformer Philip Melanchthon (Strauss 1978, Bowen 1975, 1981, Green 1979). Universities, too, were reformed and founded along Reformist lines (Paulsen 1908, Holborn 1959). Until the 18th century, Protestant Germany was the European leader in educational theory and practice (Hans 1967, Boyd and King 1975, Mitchell 1993).

What is less well-known is that traditionally education has played an important role in some other world religions as well and that these religions have also shaped educational practice since ancient times. For example, Hinduism teaches that its four aims of life - liberation (moksha), virtue (dharma), wealth (artha) and pleasure (kama) - can only be attained through knowledge (vidya) (Alpana 2011, V 2015). Although it emphasizes spiritual education, it also appreciates practical knowledge, recognizing that such knowledge is necessary to successfully navigate through the material world (Swarup 2000 [1971], Alpana 2011, Sheshagiri 2011). Historically, one of the most important educational organizations was the gurukula, the forest or community school of the guru or teacher (V 2015, Gupta 2013). These schools existed in India for 3,000 years. Teaching was based on rigid adherence to the scriptures. Until the 18th century, both children from the lower castes and girls were excluded from this as well as other types of formal education (Foster Carroll 1983).

Another less-known example of a world religion stressing the importance of education is Buddhism (Ling 1976, Bodhi 1998). In contrast to Hinduism, Buddha strongly denounced inequality on the grounds of birth and caste (Sheshagiri 2011). He taught that every person, whether male or female, had the right to be educated (Foster Carroll 1983). In the early days, Buddhist education started as simple organizations that came to be known as monasteries. Later, a definitive school system came to be attached to the monasteries (Gamage 2011). Buddhist education primarily aims at cultivating virtues, especially those that are rooted in respect and concern for others (Bodhi 1998, Chin 2002). Its fundamental purpose is the transcendental transformation of personality (Yung 2003, Samten 2009). Fields of study that are not related to such personal transformation (e.g., grammar, philosophy, medicine) are regarded as secondary (Samten 2009). Such secondary fields of study are not completely disregarded though. Quite to the contrary, they are seen as indispensable means 
to understand reality and destroy ignorance, the latter of which Buddhism regards as the root cause of suffering (Agocs 2009).

In Islam, education and academic freedom took pride of place during its golden age from the 8th to the 12th century (Nakosteen 1964, Chaney 2011). Islamic scholars translated major works from Greek, Latin, Syrian, Sanskrit and Persian into Arabic (Megahed 2011). They also made important contributions, especially to mathematics, astronomy and medicine. A system of education developed throughout the Muslim world. It consisted of an elementary and a higher level (Williamson 1987, Shamsavary et al. 1993, Megahed 2011). The elementary system, which provided education for the masses, was primarily religious, teaching the basic articles of the Qur'an and the duties of Muslims. After the Mogul invasion of the 13th century, which led to a vast destruction of manuscripts and libraries, education at all levels became confined to religious dogma and hostile to secular knowledge (Shamsavary et al. 1993, Megahed 2011). Females were excluded from the mosque, where most elementary education occurred (Foster Carroll 1983). For several centuries, girls were given only the rudiments of an Islamic education, mainly a little instruction in the Qur'an so as to be able to recite their prayers properly (Smith 1987, Jawad 1998).

Two world religions that have put comparatively little emphasis on education throughout all or most of their histories are Eastern Orthodoxy and Roman Catholicism. As the Orthodox Church regards itself as the guardian of Christian dogma and established ritual practice, it has traditionally focused more on the liturgy, prayer and spiritual guidance than on formal education (Elias 2002, Vrame 2006). Orthodox mysticism - personal experience of divine mysteries and recognition of the inadequacy of human intellect - is not conducive to formal education either (Tulasiewicz 1993). The Orthodox Church had only a limited impact on public education also because, throughout its history, it has been dominated and sidelined by the state. This was the case under the Byzantine Emperors and, after the fall of Constantinople in 1453, under the Turkish Sultans (Hans 1967). It was also the case in more recent times - particularly in Russia under the Tsars (Alston 1969, Johnson 1969) and for most of the 2oth century in the whole of eastern Europe under the Communist rulers (Matthews 1982, Ellis 1986, Ware 2015).

Under Roman Catholicism before the Reformation, school populations were small, with literacy being largely limited to the clergy and the nobility (Bowen 1981). The sole purpose of education was to secure and promote Christian faith (Boyd and King 1975). In response to the Reformation, Rome became even more conservative (Bowen 1981). It tightened control of its schools, colleges and universities, persecuted heretics (Burman 2004) and promulgated an Index of Forbidden Books (Lenard 2006). The Index, which was abolished 
as late as 1966, contained the works of eminent scholars such as Copernicus, Bacon, Kepler, Galileo, Pascal, Locke and Hume. As another measure of fighting Protestantism, several Catholic orders were founded in the 16th century. The most important of them, the Society of Jesus, provided secondary education for boys only, and mostly for those of the upper classes (O'Malley 2014). Its education remained strictly within a theological framework approved by Rome. Until the 19th century, there were few educational opportunities for girls (Bowen 1981). During that time, the Catholic Church also neglected primary education, both in the European countries where its monopoly remained in place - e.g., Spain, Portugal and Italy - as well as in these countries' colonies, where the Church largely confined itself to converting the natives (Hans 1967, Bowen 1981, Burkholder and Johnson 2014).

While historically, religious organizations were the first, and for many centuries the only institutions providing some kind of formal education, ever since the age of Enlightenment, the formal role of religion in education has been strongly diminished, especially in the West. Education was almost completely secularized and the school systems were taken over by the state, either entirely or for the most part (Boyd and King 1975). However, for several reasons some world religions are likely to have continued to influence schooling even in the recent past, at least to some degree. First, most people still identify with a religious group. In 2010 no less than $84 \%$ of the global population were affiliated with a religion (Pew Research Center 2012). If their religion places a high emphasis on education, parents might have increasingly sent their children to school and requested policy makers to expand educational provision. Second, religious authorities with well-established links to governmental policy makers might have successfully lobbied for an expansion of schooling. Third, politicians might have expanded the supply of schooling on their own initiative if their religious beliefs induced them to do so. However, ex ante it is unclear which world religions, through these different players, have recently influenced schooling at the national level, primarily because different religions have different views on schooling and because the recent influence of religions has varied both by country and by religion - not least because other players who are not or less motivated by religion, such as teachers unions, have influenced educational provision as well. Therefore, it is impossible to make specific theoretical predictions. Rather, the question which world religions have exerted a contemporary influence on the extent of secondary schooling at the national level in the recent past needs to be resolved empirically. When discussing our regression results, we will, for each world religion, look at its views on education and its recent influence on schooling in major countries. This should enable us to correctly interpret our estimates. 
Our paper makes several contributions. First, whereas almost all previous econometric papers study the effect of a few religions only, our paper covers all major world religions. Specifically, it covers Islam, Judaism, Roman Catholicism, Protestantism, Eastern Orthodoxy, Hinduism, Buddhism and other Eastern religions (including Confucianism). Second, whereas most previous econometric papers use individual-level data, we use country-level data, which enables us to estimate the effect of these religions on national rates of schooling. Third, our paper is one of the first studies using country-level data that exploits not only variations of religious population shares across countries but also changes in such shares through time. Fourth, our sample of countries is exceptionally large. By contrast, most previous econometric studies use data from a single country only, and almost all of the few existing multi-country studies use data from far fewer countries than we do. Fifth, our sample period is much longer than those of previous studies, most of which use data from a few years only. The larger country sample combined with the longer sample period leads to more general results. Finally, unlike most previous papers using country-level data, we include a large number of controls and perform a battery of robustness checks.

The remainder of the paper is organized as follows. While section 2 briefly surveys the previous econometric literature, section 3 describes our variables and methodology. Section 4 presents and discusses our regression results. Section 5 concludes.

Almost all previous econometric studies use data from the recent past. Among the most clear-cut results from these studies are those for Islam. Particularly, almost all studies find this religion to have a negative effect on female education. Examples of multi-country studies reporting such an effect include Marshall (1985), Mincer (1996), Fish (2002), Norton and Tomal (2009), Papagapitos and Riley (2009), Cooray and Potrafke (2011) and Castelló-Climent and Hidalgo-Cabrillana (2012). Furthermore, using data on more than 6o countries from the World Values Survey, both Guiso et al. (2003) and Fish (2011) report that Muslims mostly agree with the statement, "A university education is more important for a boy than for a girl". Single-country studies, too, almost unequivocally find Islam to negatively affect female education. Examples include Mukhopadhyay's (2011) paper using Us data and Ahmed's (2007) paper, which uses data from India. Also using Indian data, Kingdon (2002) finds Islam to have a negative effect not only on females but also on males. 
Similarly, Bessey (2013) reports that in China Muslims acquire significantly less education than people with no religion.

The results for Judaism are also unambiguous, but so far all studies on this religion have used us data only. These studies consistently find Jews to acquire more education than other individuals (e.g., Chiswick 1993, Lehrer 1999, Sander 1992, 2010). The positive effect of Judaism pertains to women too. For example, Lehrer (2010) finds Jewish women to complete the most years of schooling, compared with other non-Hispanic white women. Similarly, Keysar and Kosmin (1995) report that, among white women, the odds of acquiring college education were highest among those of Jewish faith.

Results from previous research are more mixed for Protestantism. For example, Castelló-Climent and Hidalgo-Cabrillana (2012) find this religion to have no statistical significant effect in their sample of 63 countries. According to papers using data on the United States only, in this country the type of Protestantism matters. Specifically, whereas educational attainment is found to be lowest among fundamentalist or conservative Protestants, mainline Protestants are found to be at the center of the distribution (Darnell and Sherkat 1997, Lehrer 1999, 2006, 2010, Massengill 2008 and Sherkat 2011). Papers using data from the 19th century rather than from the last few decades find that Protestantism had a positive impact on schooling and educational performance in both Prussia and Switzerland (Becker and Woessmann 2009, 2010, Boppart et al. 2013, 2014). In 19th century Prussia, it also closed the gender gap in basic education (Becker and Woessmann 2008).

For Roman Catholicism, the results from previous econometric studies are mixed as well. For example, whereas Bessey (2013) finds that, in China, Japan and South Korea, Catholics acquire more education than those with no religious affiliation, Aldieri and Autiero (2013) report that, in their sample of eight Latin American countries, Catholicism has a negative effect on the probability of having achieved university education. In their much larger sample of countries, Castelló-Climent and Hidalgo-Cabrillana (2012) find the effect of Catholicism on educational attainment to be statistically insignificant. The results from studies using us data only are mixed as well. On the one hand, several studies report a negative effect. Specifically, Sherkat (2011) finds Catholics to have significantly lower levels of scientific literacy when compared with secular Americans. Mukhopadhyay (2011) reports that high religiosity reduces educational attainment for Catholic women. Goldin and Katz (2009) find that the share of Catholics had a negative effect on both school attendance and secondary school graduation rates between 1910 and 1940. On the other hand, using data from the 1980s Sander (1992), Evans and Schwab (1995) and Neal (1997) find a positive effect of Catholicism on educational attainment in the 
Us. Similarly, Vella (1999) reports a positive effect of this religion on educational attainment in contemporary Australia.

Other religions than Islam, Judaism, Protestantism and Catholicism have been covered in a few studies only. For example, only Norton and Tomal (2009), who use data on 97 countries from the early to mid-199os, additionally cover Hinduism, finding that this religion has a negative effect on female education. Both Norton and Tomal (2009) and Bessey (2013) include Eastern Orthodoxy in their regression analysis. Their results are inconclusive though. Specifically, Norton and Tomal (2009) find this religion to have a negative effect on female education in some but not in all of the relevant specifications. By contrast, according to Bessey (2013), in Taiwan Orthodox Christians spend more years in education than the religiously unaffiliated. The results for Buddhism are even more contradictory. Bessey (2013) finds that, relative to those with no religious affiliation, Buddhists acquire more education in Japan but less in Taiwan, while in China and South Korea the differences between the two groups are insignificant. Using data from the United States, Sander (2010) finds that Buddhists born in this country and/or living there at age 16 acquire more education than Protestants, but people with a Buddhist upbringing do not.

3 Variables and Methodology

\subsection{Variables}

We use the following eight religion variables: Hinduism, Buddhism, other Eastern religions, Judaism, Islam, Eastern Orthodoxy, Roman Catholicism and Protestantism. Each of these variables measures the share of the population adhering to the respective religion (for definitions, descriptive statistics and sources of all variables, see Table A1). The data are from Maoz and Henderson's (2013a) World Religion Dataset. Drawing on multiple sources, this dataset is one of only few to provide data on religion adherence for a large number of countries over a long period of time. Specifically, it gives quinquennial data for all countries over the period 1945 to 2010 (Maoz and Henderson 2013b). For two reasons, it is a substantial improvement over the previously best sources of such data, the World Christian Database (Center for the Study of Global Christianity 2015) and its predecessor, the World Christian Encyclopedia (Barrett 1982, Barrett et al. 2001). First, it provides data at more frequent intervals. Second, it avoids the key downside of the latter sources - namely, that they give higher estimates for the share of Christians in comparison to other cross-national datasets (Hsu et al. 2008).

Specific comments on three of our religion variables are in order. First, 'Buddhism' includes Shinto for Japan. This is because many Japanese combine 
elements of both religions in a syncretic fashion, yet only a small percentage of these identify themselves as Shintoists in surveys (Breen and Teeuwen 2010). Second, because only a tiny number of people identify themselves as Confucians in surveys, there is no separate variable for Confucianism. Instead, this religion is included in the group of 'other Eastern religions'. The role Confucianism has played in education across East Asia over recent decades has been large (To 1993, Starr 2012). Unfortunately, this is hard to quantify. Third, 'Protestantism' encompasses all churches that can trace their roots back to the Reformation. This includes, among many others, the Anglican Church. Counting this church as part of the Protestant movement is in line with most of the previous literature (e.g., Bowen 1981, Pew Research Center 2011, Robinson 2012).

The reference category for our religion variables is the share of the population adhering to other religions plus the share of the non-religious population. In some unreported robustness checks, we used three alternative reference categories, one at a time: Eastern religions, Islam and Christianity. When using any of these alternatives, the estimates for the included religion variables are little affected - i.e., they are similar to the estimates reported in section 4.

Our main dependent variable is the secondary enrollment rate. Because several religions have restricted the schooling of girls for a long time, we additionally use the female secondary enrollment rate as a dependent variable. We also employ the male secondary enrollment rate, to see how religions have affected the education boys in the recent past. We do not use the primary enrollment rate because in most countries primary education has been compulsory for many years.

We include a large number of variables to control for the impact of other potentially important determinants of schooling. The control variables we employ have been selected on the basis of the relevant theoretical and empirical literature. For brevity, instead of surveying this literature in detail let us just list the variables and cite some of the papers that have found the respective variable to be potentially important. To start with, we control for the share of public spending on education in GDP (e.g., Heylen and Pozzi 2007, Castelló-Climent and Hidalgo-Cabrillana 2012). Furthermore, we control for political rights and civil liberties and, in one robustness check, alternatively for the degree of autocracy/democracy (e.g., Lake and Baum 2001, Rudra and Haggard 2005, Eterovic and Sweet 2014). In another robustness check, we additionally control for religious pluralism (e.g., Alesina et al. 2003, Gruber 2005). We employ several demographic variables: life expectancy (e.g., Soares 2005, Cervellati and Sunde 2005), death rate (e.g., Kalemli-Ozcan et al. 2000, Forston 2011), urbanization rate (e.g., Mincer 1996, Bertinelli and Zou 2008) and, in one robustness check, population growth rate (e.g., Becker and Lewis 1973, Hanushek 1992). We also control for relevant economic characteristics. 
Specifically, we use GDP per capita (e.g., Mincer 1996, Papagapitos and Riley 2009), GDP growth rate as a proxy for business cycle fluctuations (e.g., DeJong and Ingram 2001, Méndez and Sepúlveda 2012), private credit as a proxy for credit constraints (e.g., De Gregorio 1996, Flug et al. 1998), openness (e.g., Findlay and Kierzkowski 1983, Ranjan 2001), physical capital stock and, in one robustness check, physical investment (e.g., Griliches 1969). In our final four robustness checks, we additionally control for economic instability and different types of crises, using the variables inflation rate, systemic banking crises, natural disasters and wars (e.g., Skidmore and Toya 2002, Heylen and Pozzi 2007, Crespo Cuaresma 2010).

\subsection{Methodology}

Our dataset of 143 countries over 1973-2012 was constructed in three steps (for a list of countries, see Appendix). In a first step, we collected panel data at annual frequency, covering as many countries and years as possible (given data availability). In a second step, we filled gaps in the data. Specifically, as data in the World Religion Dataset are available at five-year intervals only, we filled these gaps by linear interpolation. This is justifiable because religion population shares change only gradually over time. Also as part of our second step, for our religion variables we used the data for the final year in the World Religion Dataset, 2010, also for the years 2011 and 2012, the two last years of our sample period. This is preferable to linear extrapolation as the latter can quickly lead to implausible values. For our other variables, we also filled any gaps in the data by linear interpolation because, as in the case of our religion variables, the data for the most important of our other variables - namely, the three enrollment variables - also change gradually over time. Furthermore, for both our dependent variables and our control variables, data gaps were much rarer than in the World Religion Dataset. Indeed, most of our control variables, including those that display swings from year to year such as the GDP growth rate, did not have any gaps at all. In the third step of constructing our dataset, we averaged the annual data over non-overlapping five-year periods. This eliminates noise, reduces measurement error and, because in our regressions we lag our explanatory variables by one period (see below), makes it more likely that our estimates capture the effects of religions on school enrollment.

We estimate the following model:

$$
S_{i, t}=\sum_{j=1}^{8} \gamma_{j} R_{j, i, t-1}+\sum_{k=1}^{q} \beta_{k} X_{k, i, t-1}+\alpha_{i}+\lambda_{\mathrm{t}}+\varepsilon_{i, t}
$$


$S_{i, t}$ is a secondary enrollment rate variable of country $i$ in five-year period $t$, covering girls and boys either jointly or separately. $R_{j, i, t-1}$ is a vector of our eight religion variables and $X_{k, i, t-1}$ represents a vector of $q$ control variables. While $\alpha_{i}$ and $\lambda_{t}$ are country and period fixed effects, respectively, $\varepsilon_{i, t}$ is the error term.

Country fixed effects are included to control for the impact of unobserved country-specific characteristics. They are also useful in removing omitted factors that influence both school enrollment and religion adherence in the long run. Furthermore, a model with country fixed effects uses only the time-series variation within countries, not the variation between countries. This is appropriate in our case as we intend to study the contemporary influence of world religions, not any historical legacy they might have left in education. Whereas time-series variations within countries can single out contemporary effects, cross-country differences may be co-determined by historical legacies. For example, traditionally Protestant countries today may have higher enrollment rates than other countries mainly because of the influence Protestantism had on education in the distant past. In contrast to such a historical legacy, contemporary Protestantism may no longer have any or only little influence on education. It is the latter issue we are interested in.

Period effects are included to control for the impact of shocks that are common across countries. Additionally, they ensure that our estimates do not reflect over-time trends in school enrollment or religion adherence at the world level over the sample period. More generally, by using both country and period effects plus a large number of control variables we intend to ensure that our regression analysis accounts for other factors than religion that affect school enrollment, some of which may be correlated with one or more of the religion variables.

Causality may not only run from religion to education but also vice versa. Several studies using individual-level data find education to affect religiosity. ${ }^{2}$ Although there are no studies using country-level data that find education to affect religion adherence, endogeneity of our religion variables cannot be ruled out. Some or all of our control variables may be endogenous too. Unfortunately, there are no valid instruments. For example, we tried General Method of Moments (GMM). However, the results from the Hansen (1982) test of joint validity of instruments produced high $p$ values throughout, suggesting that GMM would be inappropriate in our case. The problem is probably one of

2 It is unclear whether the effect of education on religiosity (if any) is positive or negative. Studies reporting a positive effect include Brañas-Garza and Neuman (2004) and Brown and Taylor (2007). Studies reporting a negative effect include Hungerman (2014) and Mocan and Pogorelova (2014). 
instrument proliferation, i.e., the fact that the number of instruments in GMM tends to explode with the number of time periods. Instrument proliferation can overfit endogenous variables and fail to expunge their endogenous components, a telltale sign being high Hansen test $p$ values (Roodman 2009a, 2009b). We experimented with various ways of reducing the instrument count, such as limiting the lags in GMM-style instruments and collapsing instruments, but none of this solved the problem.

As neither GMM nor other forms of instrumental variables estimation are applicable, we lag all explanatory variables by one five-year period. This should lessen concerns about possible endogeneity bias. For example, whereas it is hard to imagine that future changes in the secondary enrollment rate can affect current religion adherence shares, it is very well possible that changes in religion adherence in one five-year period affect secondary enrollment in the following five-year period.

As there is no better way to address potential endogeneity, the regression analysis presented below does not establish causality. Instead, the regressions are used to measure conditional correlations, i.e., to assess whether our religion variables are statistically significant after controlling for other relevant factors. Still, the estimates for our religion variables are likely to be causal for four reasons. First, we control for most major determinants of school enrollment that have been found in the previous literature. Second, we also control for unobserved country and period effects. Third, we ensure that our religion variables do not proxy for factors such as public spending on education, political freedom or GDP per capita. Fourth, all explanatory variables enter the equation with a lag of one five-year period.

4

\section{Results and Discussion}

Tables 1 to 4 present our regression results. Tables 1 to 3 report the results from our main regressions - Table 1 for both genders combined and Table 2 (3) for girls (boys) only. In each of these tables, column 1 reports the results from our baseline regression while the other columns report the results from our main robustness checks. Table 4 presents the results from regressions in which we exclude outliers. Specifically, we exclude India and Nepal from regressions 1 to 3 and Israel from regressions 4 to 6 . As the share of Hindus is exceptionally large in India and Nepal, and similarly the share of Jews in Israel, the intention behind excluding these outliers is to see whether our main results for Hinduism and Judaism, respectively, remain unchanged. To save space, the 
estimates for the control variables are omitted from Tables 2 to 4 . In Tables 2 and 3 , each regression uses the same controls as the corresponding regression reported in the same column of Table 1 . In Table 4, each regression employs the control variables used in the baseline regression (column 1 of Table 1 ).

\subsection{Hinduism}

In each of our main regressions, the coefficient on Hinduism is positive and significant, indicating that, over the sample period, this religion has had a positive effect on secondary schooling. According to our estimates, the effect was large. Specifically, a five percentage point increase in the Hindu population share is associated with an increase in the secondary enrollment rate of about $7^{1 / 2}$ percentage points, ceteris paribus. The effect on girls is even larger, a five percentage point increase being associated with an increase in the female secondary enrollment rate of almost nine percentage points, ceteris paribus. The effect on boys is smaller but still large, a five percentage point increase in the Hindu population share being associated with an increase in the male secondary enrollment rate of more than six percentage points, ceteris paribus. When excluding India and Nepal, the coefficient on Hinduism is significant too, though slightly smaller.

The positive effect of Hinduism is probably due to a combination of the fact that this religion has traditionally highly valued education (section 1 ) and the fact that school enrollment in Hindu societies has substantially increased only in the recent past. For example, in India since independence in 1947 the government, which nowadays runs most schools, has made strenuous efforts to raise educational attainment, intending to prepare young people for the modern working world (Sebaly 1993, Sheshagiri 2011). Under the constitution, education is free and compulsory between the ages of 6 and 14 (Singh and Nath 2005). Because of high rates of teacher absenteeism and low levels of learning achievement in India's government-run schools, private schools have proliferated in recent decades. For example, between 1993 and 2002 almost $40 \%$ of the increase in enrollment occurred in the latter, and in the early 2000 s these schools accounted for approximately $30 \%$ of total enrollment (Kingdon 2007). Although private schools usually charge fees, they are used even by the poor.

In Nepal, since democracy was adopted in 1951, thousands of public schools have been established, where education is free up to the secondary level (Parajuli and Das 2013). In recent decades, private schools have proliferated in this country too. Nowadays, most middle-class families prefer to send their children to such schools, where the quality of education is much higher. In the early 2000 s, about $15 \%$ of students attended private schools (Parajuli and Das 2013). 


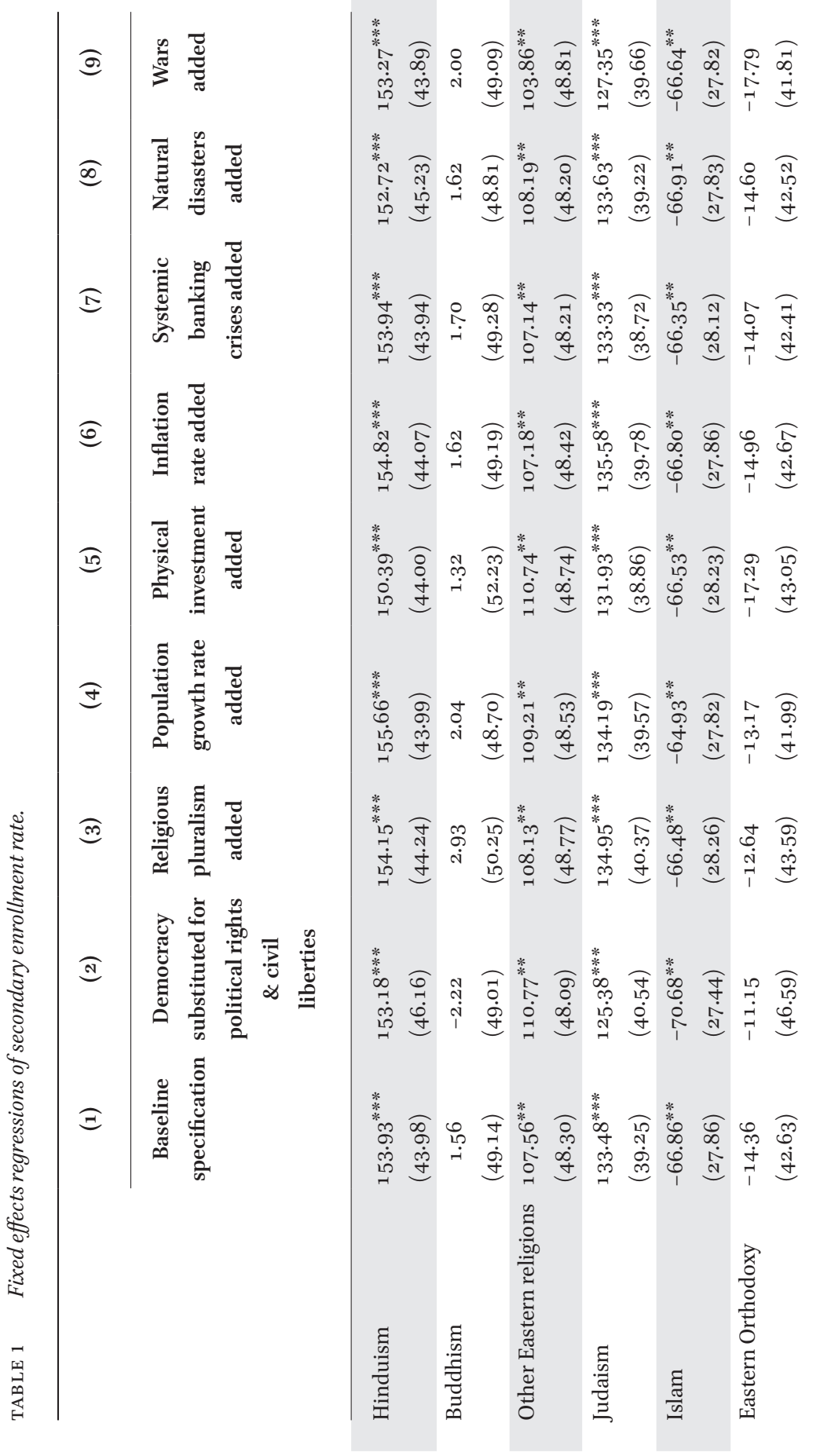




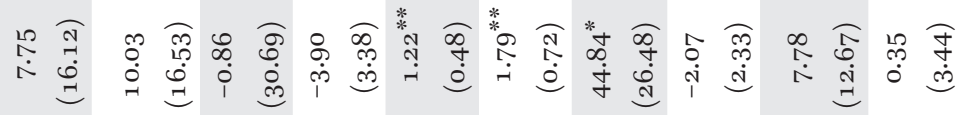

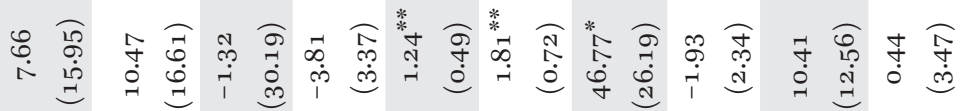

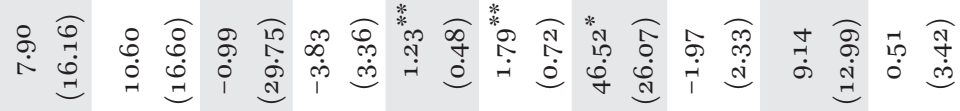

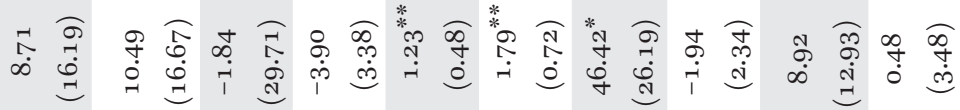

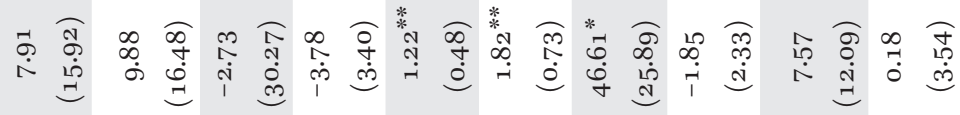

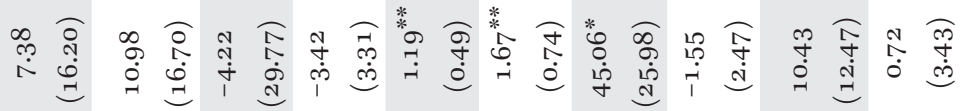

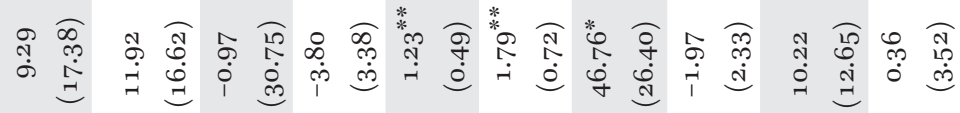

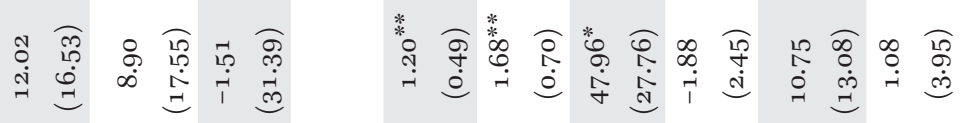

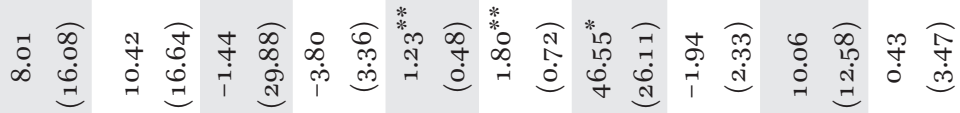

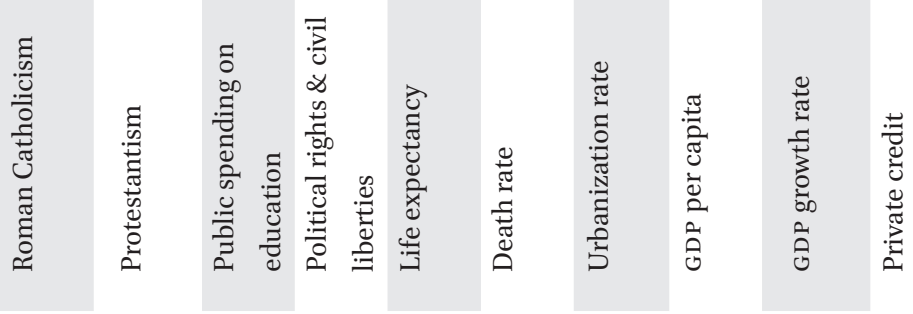




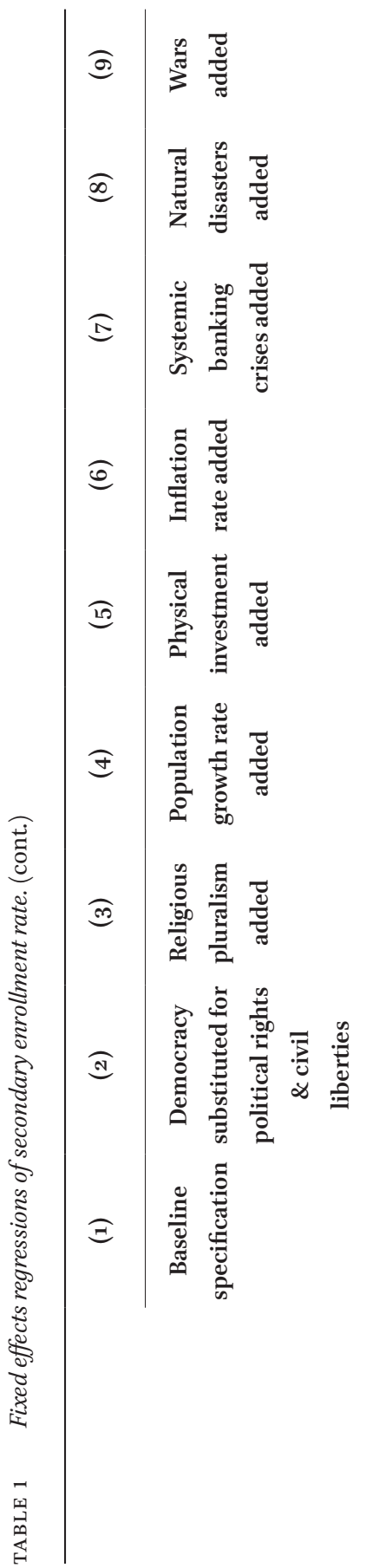

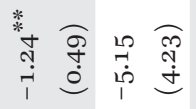

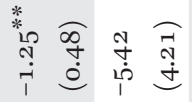

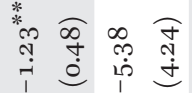

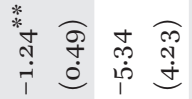

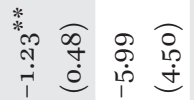

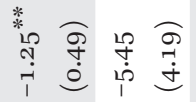

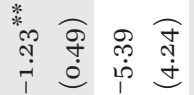

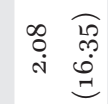

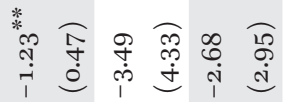

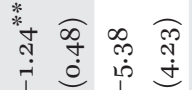

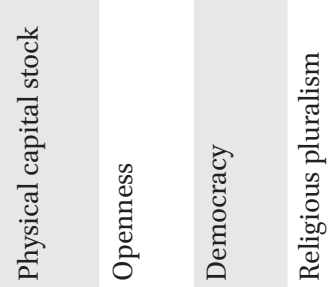

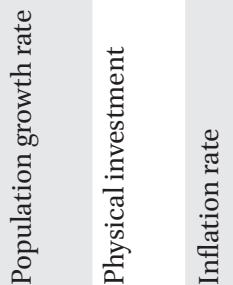

$\begin{array}{ll}+ & \widehat{8} \\ 0 & 0 \\ \dot{0} & \dot{0}\end{array}$

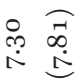

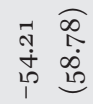
تี 


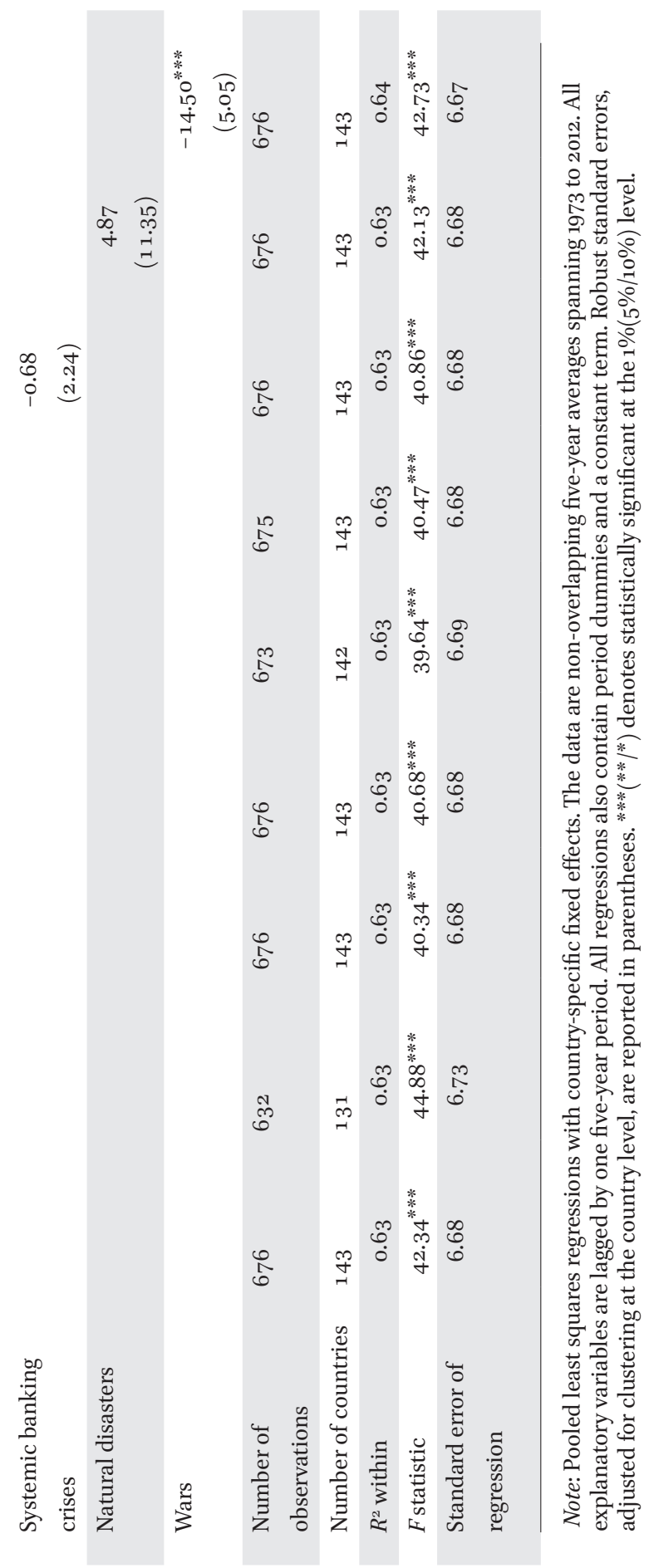




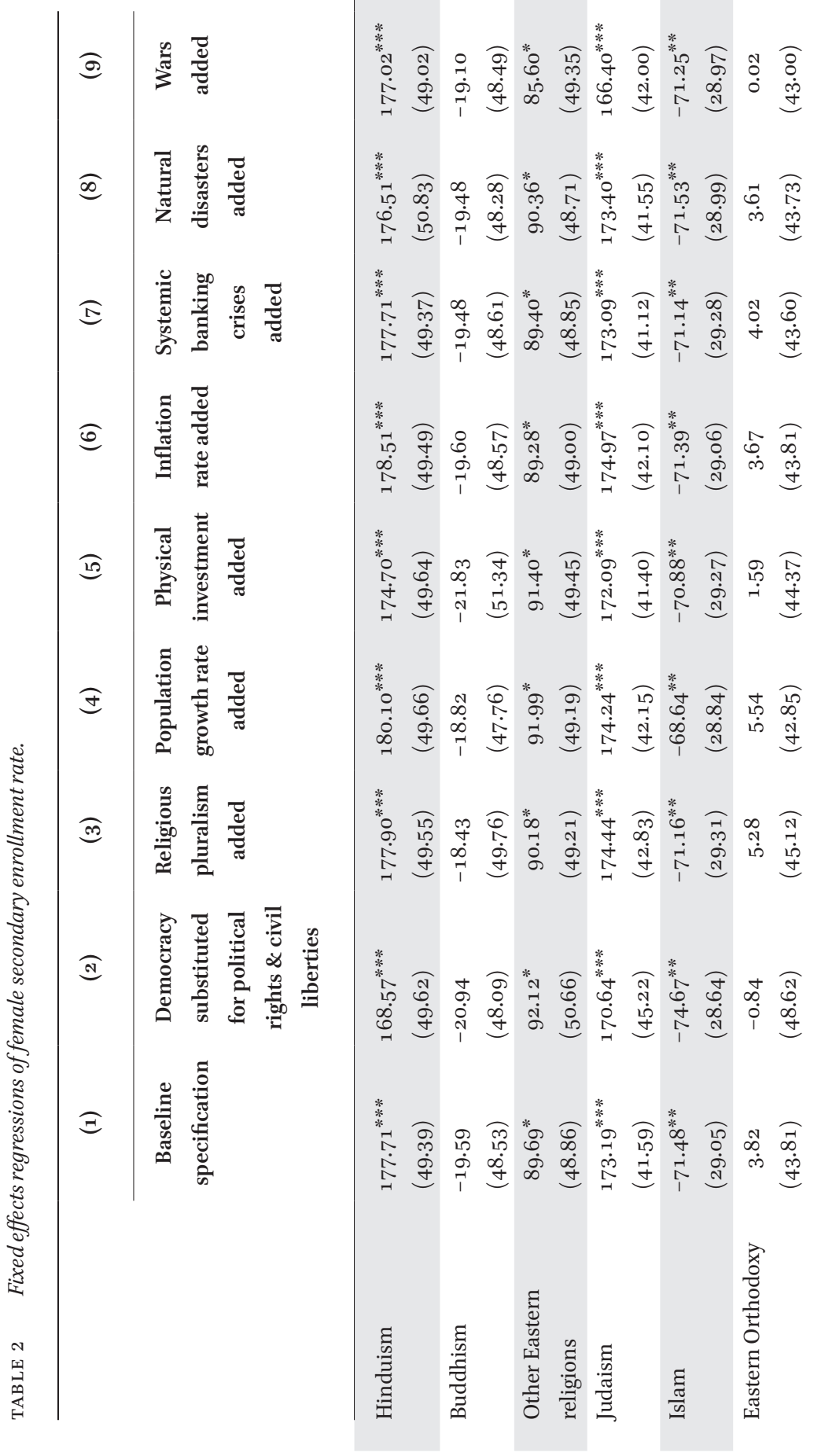




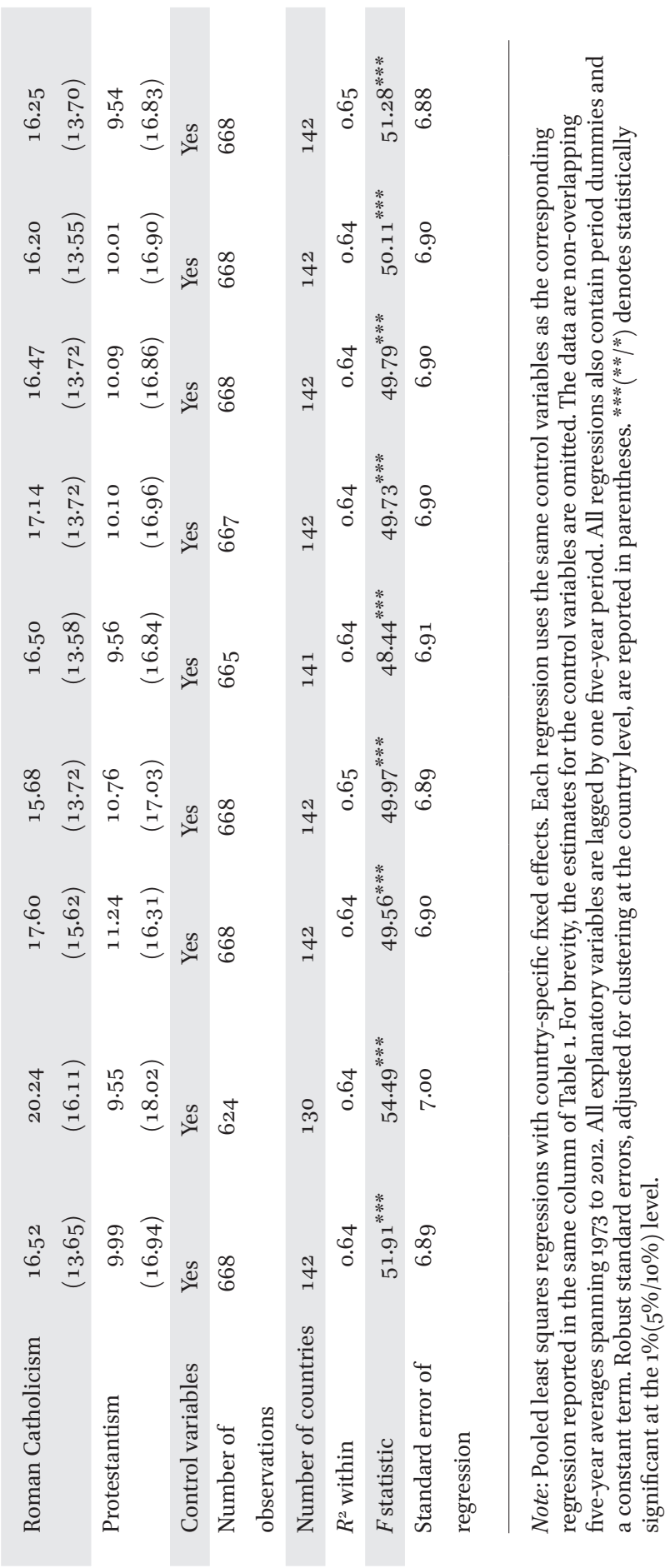




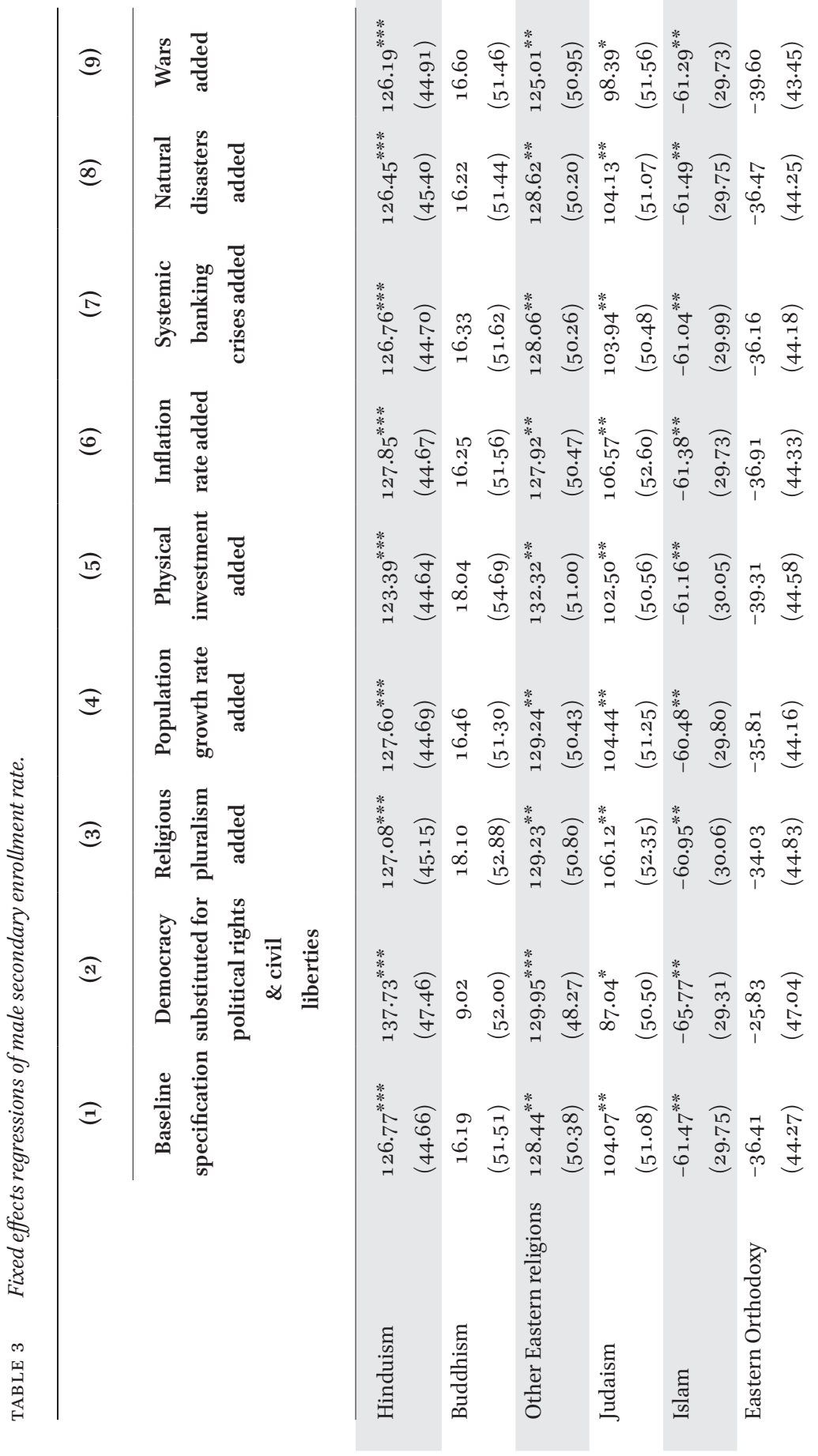




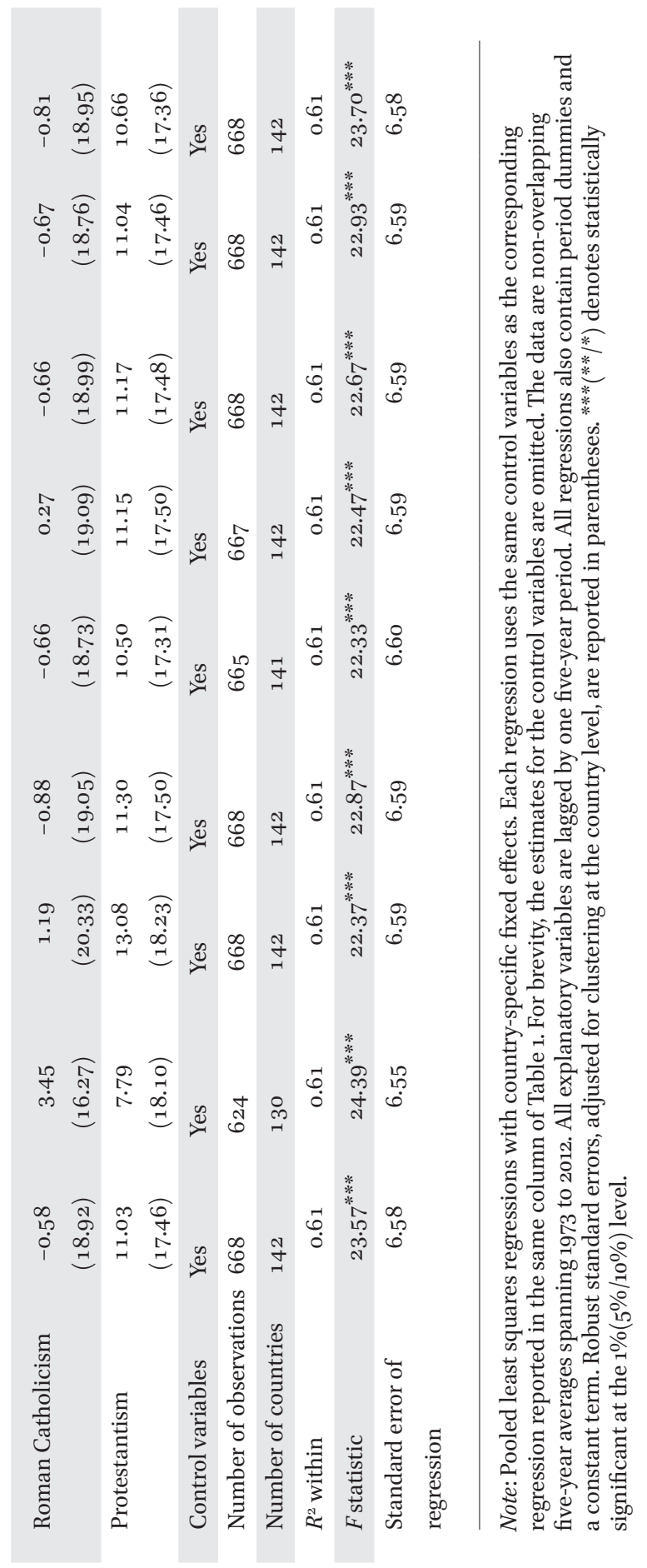




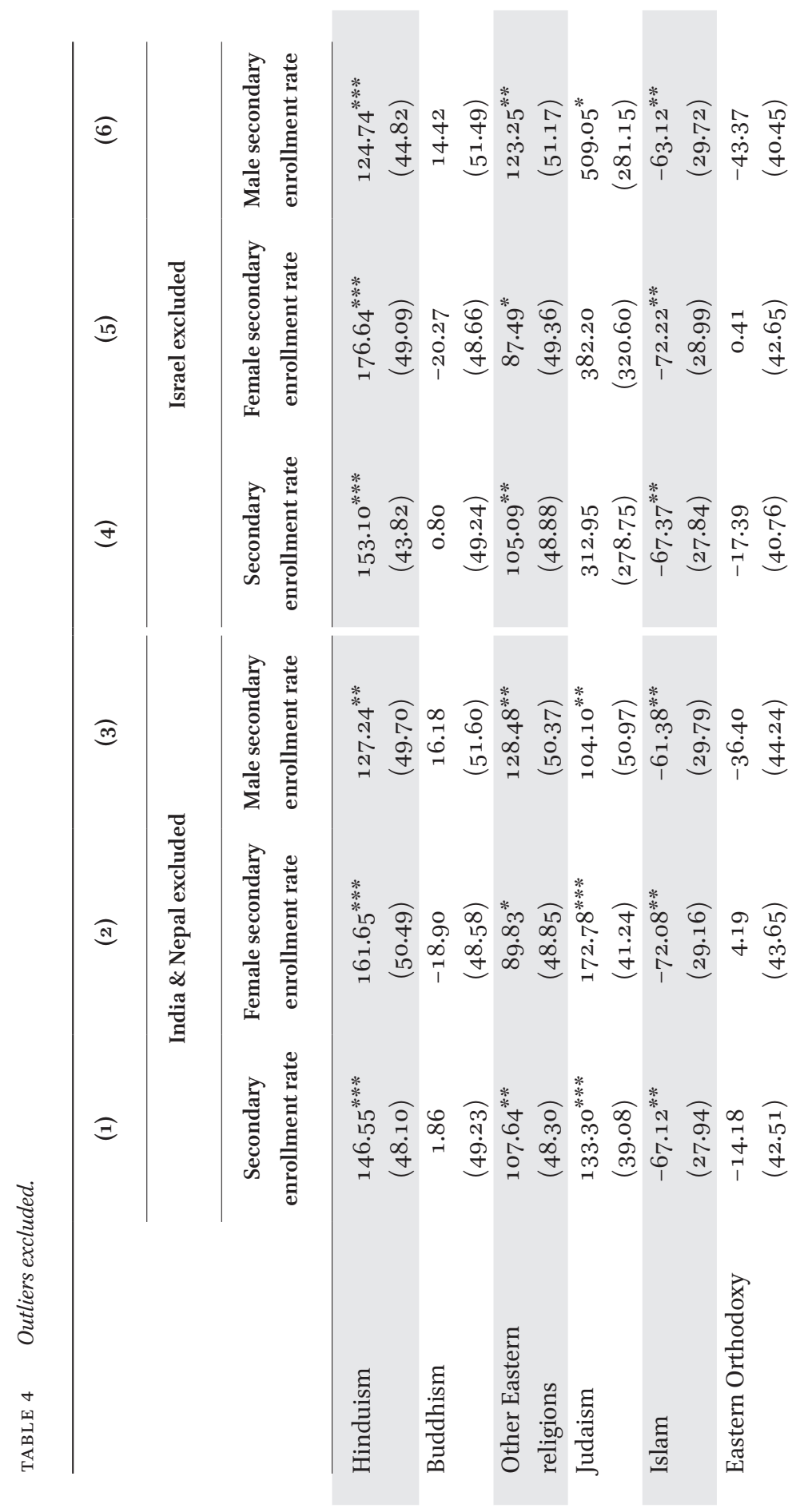




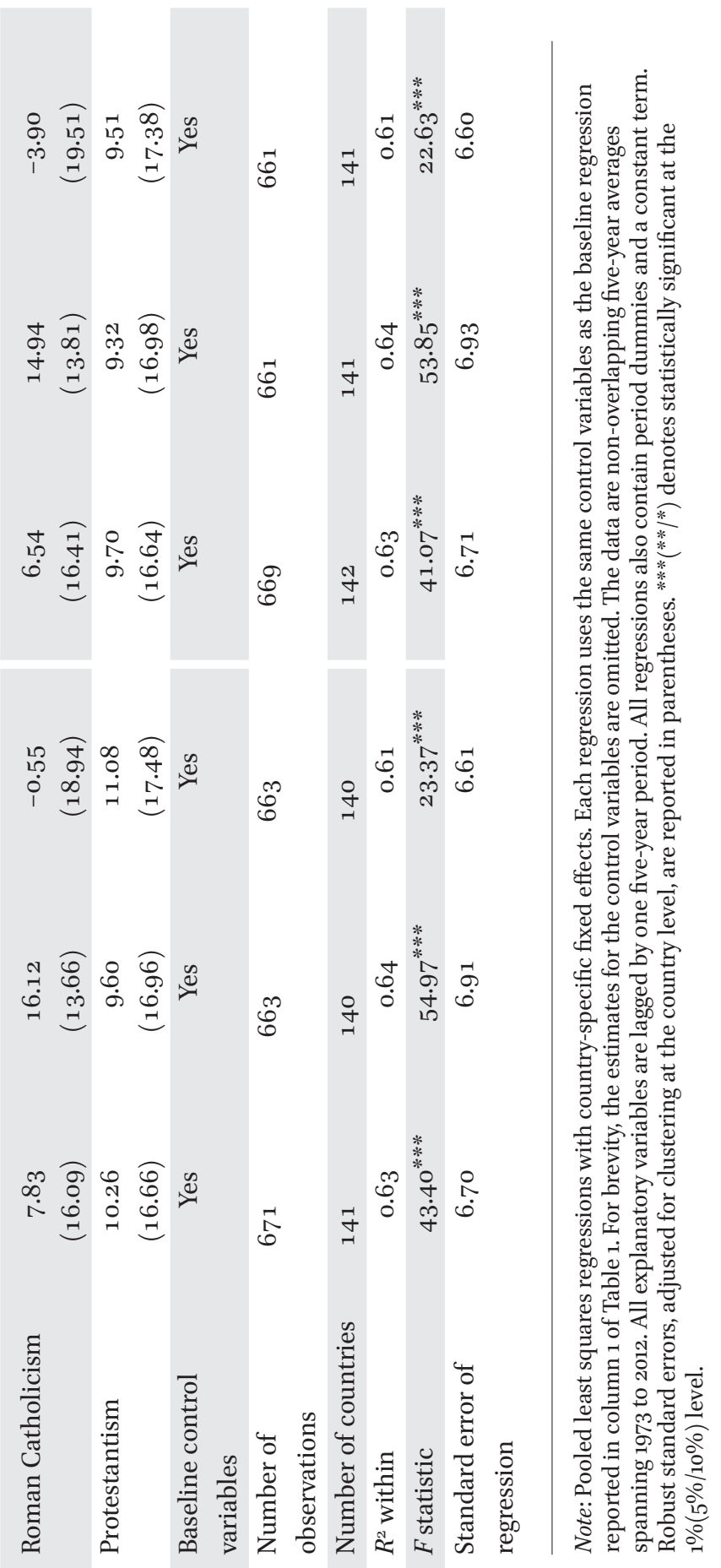


In India, Nepal as well as in Hindu communities outside these countries, Hindu parents go to great lengths to educate at least the male children in the family (Sheshagiri 2011). Over recent decades, governments in both countries, as well as in other countries with large Hindu communities, have made particular efforts to improve the education of girls and children from the lower castes (Sebaly 1993). Overall, these efforts by parents and governments have led to a strong increase in secondary enrollment, particularly of girls, during our sample period. For example, from 1973 to 2012 the secondary enrollment rate rose from $25 \%$ to $72 \%$ in India and from $13 \%$ to $66 \%$ in Nepal. Over the same period, the female secondary enrollment rate even rose from $15 \%$ to $69 \%$ in India and from as little as $4 \%$ to $67 \%$ in Nepal. These developments, which could also be observed in other countries with substantial Hindu populations, explain our estimates for the Hinduism variable. They also explain the negative effect of Hinduism on female education during the early to mid-199os found by Norton and Tomal (2009) (section 2) because back then the gender gap in education was still wide in Hindu societies.

\subsection{Buddhism}

Our estimates for the Buddhism variable are statistically insignificant throughout. This may be due to several reasons. First, there are far fewer Buddhists than Hindus around the world, and in many countries they represent only a small fraction of the population. Second, Buddhist education prioritizes the transcendental transformation of personality over public schooling (section 1). For both reasons, Buddhism might have had little impact on national school enrollment rates.

However, there is a third possible reason why our estimates for this religion are insignificant. Because of Buddhism's strong focus on education, its appreciation of secular education (although ranked second) and its request to provide education for all people without discrimination, education has been held in high esteem among the general population of traditionally Buddhist countries for centuries. Therefore, for many years most of these countries have had unusually high rates school enrollment among both genders, especially compared with other developing countries (Gamage and Setunga 2011). For example in Sri Lanka the secondary enrollment rate was $52 \%$ as early as 1973 and the female secondary enrollment rate $49 \%$ in 1976 - far ahead of India and Nepal at the time. As we use country fixed effects (to identify recent effects of religions) the coefficient on 'Buddhism' could be insignificant because secondary enrollment was already high in Buddhist countries at the beginning of our sample period and consequently subsequent further increases have been limited. 


\subsection{Other Eastern Religions}

The estimates for the 'other Eastern religions' variable are significant and positive. Specifically, a five percentage point increase in the population share of adherents to this group of religions is associated with a rise of more than five percentage points in the secondary enrollment rate, ceteris paribus. While the effect on girls is slightly smaller than on both genders combined, 4 1/2 percentage points, the effect on boys is larger, more than six percentage points, ceteris paribus.

Apart from Confucianism, the group of other Eastern religions consists of Taoism, Jainism, Shinto (except for Japan) and Sikhism. Similar to Confucianism, the number of adherents to these religions is small. Furthermore, neither in Taoism nor in Jainism, Shinto and Sikhism does formal education figure prominently in their doctrines. Taoism, for example, regards formal institutions such as schools with suspicion. For the Taoist, education is a sole quest (Ford 1998). In this religion, education's purpose is to encourage self-reflection to find one's true self and to take the path to truth (Ornstein et al. 2013). Therefore, the positive effect of the 'other Eastern religions' variable is probably solely due to Confucianism. Although even in Confucian heritage societies only few people identify themselves as adherents to this religion in surveys, over our sample period it has had a profound and increasing influence on education in these societies (To 1993, Yang 1993, Starr 2012). In line with Confucian values and principles, in recent decades these societies have placed a strong emphasis on education, regarding it as both the most promising way for character development and as a pathway to upward social mobility. Also in line with Confucian values and principles, educational practice in these societies has been characterized by hard work and relentless assessment.

Partly due to the rising influence of Confucianism, school enrollment has increased strongly and to a high level in Confucian heritage societies over our sample period. For example, in South Korea from 1973 to 2011, the secondary enrollment rate rose from $47 \%$ to $97 \%$ and the female secondary enrollment rate from $38 \%$ to $96 \%$. Equally, in China the secondary enrollment rate rose from $52 \%(1973)$ to $89 \%$ (2012) and the female secondary enrollment rate from $46 \%$ (1976) to $90 \%$ (2012). In Japan from 1973 to 2012 both the secondary enrollment rate and the female secondary enrollment rate rose from $90 \%$ to $102 \%$. Because only a tiny number of people identify themselves as Confucians and because the group of 'other Eastern religions' also includes religions that place no special emphasis on formal education, the coefficient on 'other Eastern religions' probably underestimates the magnitude of the effect of Confucianism on secondary schooling over the sample period. 


\section{$4.4 \quad J u d a i s m$}

Our estimates for the Judaism variable indicate that this religion has had a substantial positive effect on secondary enrollment in the recent past. Specifically, a five percentage point increase in the Jewish population share is associated with a rise in the secondary enrollment rate of about $6 \frac{1}{2}$ percentage points, ceteris paribus. Interestingly, the estimated effect for girls is larger than for boys. Specifically, while a five percentage point increase in the share of Jews among the population is associated with an $81 / 2$ percentage point rise in the female secondary enrollment rate, the corresponding rise in the male secondary enrollment rate is just five percentage points, ceteris paribus. In any case, our positive results accord with previous econometric studies, which use individual-level data from the us (section 2).

However, when excluding Israel from our sample, the coefficient on Judaism is statistically insignificant (except in the case of boys, where it is marginally significant). This is unsurprising. Whereas in Israel over our sample period $80 \%$ of the population was Jewish, in almost all other countries the share was below $0.1 \%$. In the US it was $2 \%$. Therefore, Judaism is likely to have noticeably influenced national rates of secondary enrollment in Israel only.

This is not to deny that Jews outside Israel have continued to cherish education in modern times. Quite to the contrary. From the late 18th century, Jewish schooling was modernized, especially in western countries (Iram 1993). Secular subjects and the country's language were introduced. Girls were finally admitted to school. After the Holocaust and the founding of the State of Israel, Jewish communities around the world renewed their interest in Jewish learning and Jewish identity (Zeldin 2011). At the same time, most Jews continued to increasingly integrate with the modern world and embrace secular learning (Miller et al. 2011). As a result, there emerged a religious/secular bifurcation in education among Jews, which has been most clearly evident in Israel (Iram 1993). While in the recent past the majority of Israeli children have attended state-secular schools, a substantial minority have attended state-religious or ultra-Orthodox schools, the latter of which exclude secular subjects such as mathematics and science. Still, overall school enrollment in both Israel and Jewish communities elsewhere has been further increased, reaching high levels. For example, in Israel from 1973 to 2012 the secondary enrollment rate rose from $75 \%$ to $101 \%$ and the female secondary enrollment rate from $78 \%$ to $103 \%$.

\subsection{Islam}

In line with previous econometric studies (section 2), we find that Islam has had a substantial negative effect on education, particularly of females. Specifically, 
a five percentage point increase in the share of Muslims in the population is associated with a reduction of the secondary enrollment rate of slightly more than three percentage points and with a reduction of the female secondary enrollment rate of $3 \frac{1}{2}$ percentage points, ceteris paribus. Interestingly, Islam has also had a large negative effect on the education of boys, a five percentage point increase in the Muslim population share being correlated with a three percentage point reduction in the male secondary enrollment rate, ceteris paribus.

These negative effects are in spite of the fact that since the mid-2oth century all Muslim countries have made strenuous efforts to improve education. Most have combined secular education with the promotion of Islamic culture and values (Shamsavary et al. 1993). The weights attached to each have varied from country to country though. At one end of the spectrum is Turkey, which for many decades after the proclamation of the republic in 1923 attempted to secularize and westernize education (Williamson 1987, Lewis 2002). In the middle of the spectrum are moderate Muslim countries such as Indonesia. In its public schools, there has been a secular emphasis, which has been resented by many Muslims (Kuipers 2011). Therefore, a distinct minority of Muslim Indonesians has sent their children to Islamic schools, where secular subjects take a back seat and teaching focuses on the Qur'an as well as on Muslim traditions and history (Kuipers 2011). At the other end of the spectrum are strictly Islamic countries such as Iran, where after the 1979 Islamic revolution the whole education system was Islamized (Mehran 1992a, 1992b).

In many Muslim countries, the secondary enrollment rate rose markedly over our sample period. For example, from 1973 to 2012 it increased from $29 \%$ to $86 \%$ in Turkey, from $19 \%$ to $83 \%$ in Indonesia and from $37 \%$ to $86 \%$ in Iran. However, in other Muslim countries it was still very low in 2012 - e.g., in Bangladesh at $54 \%$ and Pakistan at $37 \%$. The female secondary enrollment rate also rose markedly in many Muslim countries from 1973 to 2012 - for example, in Turkey form $17 \%$ to $84 \%$, in Indonesia from $14 \%$ to $84 \%$ and in Iran from $26 \%$ to $83 \%$. But in Bangladesh and Pakistan in 2012, it was still just $57 \%$ and $31 \%$, respectively. In most Muslim countries, the education of women has still been hampered by traditional gender roles. Many girls are raised with the sole goal of being married, and after marriage a woman's primary role is to bear and raise children (Jawad 1998, Ibrahim 2011). The fact that we estimate a negative effect of Islam on the secondary enrollment rate, especially among females, suggests that the growth in that rate in most Muslim countries has been due to other factors - probably mainly the rise in life expectancy, urbanization and the general increase in living standards. 


\subsection{Christianity}

The coefficients on each of the three Christianity variables are statistically insignificant throughout. However, the reasons for these insignificant results vary somewhat by religion. In the case of Eastern Orthodoxy, the main reason is that, during our sample period, the Orthodox Church continued to have hardly any influence on public education, even in countries where a large majority of the population has adhered to this religion. This has been the case in, for example, Greece - in spite of the fact that the Greek constitution mentions Eastern Orthodoxy as the prevailing religion. All education in Greek schools, including religious education, has been exclusively under the authority of the Ministry of Education and Religious Affairs (Karamouzis 2015, Koukounaras Liagkis 2015). In Russia, where the Orthodox Church re-appeared in public life since the late 1980 s, the Church has also been unable to gain much influence on public education (Richters 2013). There, even after the collapse of Communism, education has been provided almost exclusively by the state and regulated by the Ministry of Education and Science.

For two reasons Eastern Orthodoxy has had hardly any influence on public education over our sample period. First, the Orthodox Church has continued to be dominated by the state. Second, it still did not develop a more open and formal approach to education (Vrame 2006). The Church has continued to focus almost exclusively on religious education and to regard sacramental participation, prayer, fasting and veneration of icons as key elements of such education (e.g., Vrame 1999). It has still appeared to be dismissive of mass schooling and renunciatory of secular education.

The insignificant estimate for the Roman Catholicism variable is also largely due to a lack of influence on education. Over the course of the 19th and 2oth centuries, the influence of the Catholic Church in education gradually diminished even in strongly Catholic countries. During the 19th century, the Church opposed the expansion and secularization of education pursued by most governments in industrializing countries (Hans 1967). In 1929, Pope Pius XI promulgated Divini Illius Magistri, the Church's only major encyclical letter on education. As by that time the Church was no longer in control of education, the Pope accepted the role of the state in developing and maintaining educational systems (Elias 2002). However, the encyclical also explicitly denied equal education of boys and girls (Foster Carroll 1983).

The Second Vatican Council (1962-65) finally took major steps towards modernizing the Catholic Church's views on education. Its declaration Dignitatis humanae called for an elimination of indoctrination and manipulation, 
especially when dealing with the uneducated (Elias 2002). Gaudium et spes recognized the right of women to acquire an education equal to that of men (Foster Carroll 1983). And Gravissimum educationis, the Church's latest major declaration on education, stated that all people have a right to education and recognized that the role of the school includes the task of preparing students for professional life (Fleming 2006).

From 1973 to 2012, the secondary enrollment rate increased markedly in almost all strongly Catholic countries. For example, it rose from $65 \%$ to $102 \%$ in Italy, from $59 \%$ to $131 \%$ in Spain and from $26 \%$ to $85 \%$ in Mexico. Over the same period the gender gap in education was eliminated in these and several other strongly Catholic countries. Although these developments were probably facilitated by the modernization of the Catholic Church's views on education during the Second Vatican Council, the fact that the coefficient on Roman Catholicism is statistically insignificant in each of our regressions suggests that this religion was no decisive factor behind the general rise in secondary enrollment over our sample period.

The fact that our estimates for Protestantism are insignificant too may be surprising at first glance. After all, this branch of Christianity has strongly advocated education from the outset and was instrumental in expanding educational provision in many countries, not only in western and northern Europe but also in many (former) colonies of European Protestant countries (Hans 1967, Bowen 1981). However, in several regards Protestantism became the victim of its own success. First, because it had successfully lobbied for education of both boys and girls for a long time, in most Protestant countries the secondary enrollment rate was very high for both genders already at the beginning of our sample period. Thus, even if Protestantism had still been influential in educational policy during that period, there was little more to accomplish. Given that our methodology exploits variation within but not between countries (to single out recent effects), this partly explains our insignificant coefficient on Protestantism. A second and more fundamental reason is that in almost all Protestant countries from the 19th century this religion lost nearly all of its previously strong influence in education as school systems were taken over by the state and education in government-run schools was secularized (Hans 1967, Mitchell 1993). Ironically, it had been the Protestant reformers who, from the outset, had argued that schools should be run by the state and that children needed not only religious but also secular education. Thus, by initiating the process of secularization, Protestantism unintentionally helped to eventually nearly completely eliminate its own influence on education. 
Our regression results indicate that several world religions have affected national rates of secondary school enrollment in the recent past. Specifically, whereas Hinduism, other Eastern religions and Judaism are likely to have had a positive effect, Islam is likely to have had a negative effect. The magnitude of the estimated effects of Hinduism and Judaism is large, especially among females. The effect of the group of other Eastern religions is slightly smaller but substantial nonetheless and - in contrast to Hinduism, Judaism and Islam - it is larger among boys than among girls. The magnitude of the estimated effect of Islam is smaller still but also substantial, especially among girls. Furthermore, we find that neither Buddhism nor the three branches of Christianity - Eastern Orthodoxy, Roman Catholicism and Protestantism - have a statistically significant effect. As set out in detail in section 4, the estimates for each of the world religions covered can be readily explained by their views on education and their recent influence on schooling in major countries.

As mentioned in section 3 , the evidence provided in this paper corresponds to conditional correlations in the data. It does not establish causality. Still, the fact that the religion and control variables enter the equation with a lag of a five-year period as well as the fact that our findings are robust, even after controlling for many factors, is intriguing and suggests that the effects are likely to be causal.

As pointed out in section 1, our paper adds to the literature in several ways most importantly by covering all major world religions, employing countrylevel rather than individual-level data and by using an exceptionally large sample of countries as well as a long sample period. Although we control for many factors and our results are robust, more research is needed. Most importantly, the ways in which the various world religions nowadays affect the demand for and the supply of schooling need to be systematically studied. Furthermore, the historical legacies of the various world religions need to be better disentangled from their contemporary ability to affect education.

\section{References}

Agocs, Tamas. 2009. "Buddhist Education and Modern Education: Compatible or Incompatible?" Available at https://dharmadana.wordpress.com, accessed 20 August 2015.

Ahmed, Shahid. 2007. "Socioeconomic Determinants of Female Education in a Muslim Family: An Econometric Analysis." Indian Economic Journal 54(4):140-152. 
Aldieri, Luigi and Giuseppina Autiero. 2013. "Religious Values, Secular Education and Development: Empirical Evidence from Some Latin American Countries." Review of Applied Socio-Economic Research 5(1): 15-32.

Alesina, Alberto, Arnaud Devleeschauwer, William Easterly, Sergio Kurlat and Romain Wacziarg. 2003. "Fractionalization." Journal of Economic Growth 8(2): 155-194.

Alexander, Hanan A. and Shmuel Glick. 2003. "The Judaic Tradition." Pp. 33-49 in A Companion to the Philosophy of Education, edited by Randall Curren. Chichester: Wiley-Blackwell.

Alpana, Reema. 2011. "The Hindu Philosophy of Education." Available at https://rimzie. wordpress.com, accessed 20 August 2015.

Alston, Patrick L. 1969. Education and the State in Tsarist Russia. Stanford (CA): Stanford University Press.

Barrett, David B. 1982. World Christian Encyclopedia. Oxford: Oxford University Press.

Barrett, David B., George T. Kurian and Todd M. Johnson. 2001. World Christian Encyclopedia, 2nd ed. Oxford: Oxford University Press.

Becker, Gary S. and H. Gregg Lewis. 1973. "On the Interaction between the Quantity and Quality of Children." Journal of Political Economy 81(2, 2): S279-S288.

Becker, Sascha O. and Ludger Woessmann. 2008. "Luther and the Girls: Religious Denomination and the Female Education Gap in Nineteenth-Century Prussia." Scandinavian Journal of Economics 110(4): 777-805.

Becker, Sascha O. and Ludger Woessmann. 2009. "Was Weber Wrong? A Human Capital Theory of Protestant Economic History." Quarterly Journal of Economics 124(2): $531-596$.

Becker, Sascha O. and Ludger Woessmann. 2010. "The Effect of Protestantism on Education before the Industrialization: Evidence from 1816 Prussia." Economics Letters 107(2): 224-228.

Bertinelli, Luisito and Benteng Zou. 2008. "Does Urbanization Foster Human Capital Accumulation?" Journal of Developing Areas 41(2): 171-184.

Bessey, Donata. 2013. "Religion and Educational Attainment in East Asia: First Evidence from the East Asian Social Survey." Global Economic Review 42(3): 238-250.

Bodhi, Bhikkhu. 1998. "Aims of Buddhist Education." Available at http://www.access toinsight.org, accessed 20 August 2015.

Boppart, Timo, Josef Falkinger, Volker Grossmann, Ulrich Woitek and Gabriela Wüthrich. 2013. "Under Which Conditions Does Religion Affect Educational Outcomes?" Explorations in Economic History 50(2): 242-266.

Boppart, Timo, Josef Falkinger and Volker Grossmann. 2014. "Protestantism and Education: Reading (the Bible) and other Skills." Economic Inquiry 52(2): 874-895.

Botticini, Maristella and Zvi Eckstein. 2012. The Chosen Few: How Education Shaped Jewish History, 70-1492. Princeton (NJ): Princeton University Press. 
Bowen, James. 1975. A History of Western Education, Vol. 2: Civilization of Europe - Sixth to Sixteenth Century. London: Methuen.

Bowen, James. 1981. A History of Western Education, Vol. 3: The Modern West, Europe and the New World. London: Methuen.

Boyd, William and Edmund J. King. 1975. The History of Western Education, 11th ed. London: Black.

Brañas-Garza, Pablo and Shoshana Neuman. 2004. "Analyzing Religiosity within an Economic Framework: The Case of Spanish Catholics." Review of Economics of the Household 2(1): $5^{-22 .}$

Breen, John and Mark Teeuwen. 2010. A History of Shinto. Chichester: Wiley-Blackwell. Brickman, William W. 2008. "Education" (Encyclopaedia Judaica). Available at http:// www.jewishvirtuallibrary.org, accessed 14 September 2015.

Brown, Sarah and Karl Taylor. 2007. "Religion and Education: Evidence from the National Child Development Study." Journal of Economic Behavior and Organization 63(3): 439-46o.

Burkholder, Mark A. and Lyman L. Johnson. 2014. Colonial Latin America, 9th ed. Oxford: Oxford University Press.

Burman, Edward. 2004. The Inquisition: The Hammer of Heresy. Stroud: Sutton.

Carmody, Denise L. 1987. “Judaism.” Pp. 183-206 in Women in World Religions, edited by Arvind Sharma. Albany (NY): State University of New York Press.

Castelló-Climent, Amparo and Ana Hidalgo-Cabrillana. 2012. "The Role of Educational Quality and Quantity in the Process of Economic Development." Economics of Education Review 31(4): 391-409.

Center for the Study of Global Christianity. 2015. "World Christian Database." Available at http://www.worldchristiandatabase.org.

Centre for Research on the Epidemiology of Disasters - CRED. 2014. "International Disasters Database (EM-DAT)." Available at http://www.emdat.be, accessed 20 June 2014.

Cervellati, Matteo and Uwe Sunde. 2005. "Human Capital Formation, Life Expectancy, and the Process of Development." American Economic Review 95(5): 1653-1672.

Chaney, Eric. 2011. "Islam and Human Capital Formation: Evidence from Premodern Muslim Science." Pp. 81-92 in The Oxford Handbook of the Economics of Religion, edited by Rachel M. McCleary. Oxford: Oxford University Press.

Chin, Kung. 2002. "Buddhism as an Education." Available at http://www.buddhanet .net, accessed 31 August 2015.

Chiswick, Barry R. 1993. "The Skills and Economic Status of American Jewry: Trends over the Last Half-Century." Journal of Labor Economics 11(1, 1): 229-242.

Cooray, Arusha and Niklas Potrafke. 2011. "Gender Inequality in Education: Political Institutions or Culture and Religion?" European Journal of Political Economy 27(2): 268-280. 
Crespo Cuaresma, Jesus. 2010. "Natural Disasters and Human Capital Accumulation." World Bank Economic Review 24(2): 280-302.

Darnell, Alfred and Darren E. Sherkat. 1997. "The Impact of Protestant Fundamentalism on Educational Attainment.” American Sociological Review 62(2): 306-315.

De Gregorio, José. 1996. "Borrowing Constraints, Human Capital Accumulation, and Growth." Journal of Monetary Economics 37(1): 49-71.

DeJong, David N. and Beth F. Ingram. 2001. "The Cyclical Behavior of Skill Acquisition." Review of Economic Dynamics 4(3): 536-561.

Elias, John L. 2002. A History of Christian Education: Protestant, Catholic, and Orthodox Perspectives. Malabar (FL): Krieger.

Ellis, Jane. 1986. The Russian Orthodox Church: A Contemporary History. London: Croom Helm.

Eterovic, Dalibor S. and Cassandra M. Sweet. 2014. "Democracy and Education in Twentieth-Century Latin America." Economics and Politics 26(2): 237-262.

Evans, William N. and Robert M. Schwab. 1995. "Finishing High School and Starting College: Do Catholic Schools Make a Difference?” Quarterly Journal of Economics 110(4): 941-974.

Feenstra, Robert C., Robert Inklaar and Marcel P. Timmer. 2013. "Penn World Table 8.o." Available at http://www.rug.nl/research/ggdc/data/penn-world-table, accessed 23 July 2013.

Findlay, Ronald and Henryk Kierzkowski. 1983. "International Trade and Human Capital: A Simple General Equilibrium Model." Journal of Political Economy 91(6): 957-978.

Fish, M. Steven. 2002. "Islam and Authoritarianism." World Politics 55(1): 4-37.

Fish, M. Steven. 2011. Are Muslims Distinctive? A Look at the Evidence. Oxford: Oxford University Press.

Fleming, G. P. (Joe). 20o6. "Catholic Church Documents on Religious Education." Pp. 607-620 in International Handbook of the Religious, Moral and Spiritual Dimensions in Education, Part 1, edited by Marian de Souza, Gloria Durka, Kathleen Engebretson, Robert Jackson and Andrew McGrady. Dordrecht: Springer.

Flug, Karnit, Antonio Spilimbergo and Erik Wachtenheim. 1998. "Investment in Education: Do Economic Volatility and Credit Constraints Matter?" Journal of Development Economics 55(2): 465-481.

Ford, Shawn. 1998. "Reconciling Taoism and Confucianism." Available at http://www2 .hawaii.edu, accessed 4 September 2015.

Forston, Jane G. 2011. "Mortality Risk and Human Capital Investment: The Impact of HIV/AIDs in Sub-Saharan Africa." Review of Economics and Statistics 93(1):1-15.

Foster Carroll, Theodora. 1983. Women, Religion, and Development in the Third World. New York: Praeger. 
Freedom House. 2014. "Freedom in the World 2014." Available at https://freedomhouse. org, accessed 20 April 2014.

Gamage, David T. 2011. "A Cultural Overview of the Education Systems in Buddhist Countries." Pp. 389-402 in Handbook of Asian Education: A Cultural Perspective, edited by Yong Zhao, Jing Lei, Guofang Li, Ming Fang He, Kaori Okano, Nagwa Megahed, David Gamage and Hema Ramanathan. New York: Routledge.

Gamage, David T. and Prasad Setunga. 2011. "Developments in the Sri Lankan System of Education: Third Century BC to the Twenty-First Century AD." Pp. 403-424 in Handbook of Asian Education: A Cultural Perspective, edited by Yong Zhao, Jing Lei, Guofang Li, Ming Fang He, Kaori Okano, Nagwa Megahed, David Gamage and Hema Ramanathan. New York: Routledge.

Goldin, Claudia and Lawrence F. Katz. 2009. "Why the United States Led in Education: Lessons from Secondary School Expansion, 1910 to 1940." Pp. 143-178 in Human Capital and Institutions: A Long Run View, edited by David Eltis, Frank D. Lewis and Kenneth L. Sokoloff. Cambridge: Cambridge University Press.

Green, Lowell. 1979. "The Education of Women in the Reformation." History of Education Quarterly 19(1): 93-116.

Griliches, Zvi. 1969. "Capital-Skill Complementarity." Review of Economics and Statistics $51(4): 465-468$.

Gruber, Jonathan H. 2005. "Religious Market Structure, Religious Participation, and Outcomes: Is Religion Good for You?" Advances in Economic Analysis and Policy 5(1): $1-30$.

Guiso, Luigi, Paola Sapienza and Luigi Zingales. 2003. "People's Opium? Religion and Economic Attitudes." Journal of Monetary Economics 50(1): 225-282.

Gupta, Amita. 2013. Early Childhood Education, Postcolonial Theory, and Teaching Practices and Policies in India: Balancing Vygotsky and the Veda, revised edition. New York: Palgrave Macmillan.

Hans, Nicholas. 1967. Comparative Education: A Study of Educational Factors and Traditions, 3rd ed. London: Routledge \& Kegan Paul.

Hansen, Lars Peter. 1982. "Large Sample Properties of Generalized Method of Moments Estimators." Econometrica 50(4):1029-1054.

Hanushek, Eric A. 1992. "The Trade-off between Child Quantity and Quality." Journal of Political Economy 100(1): 84-117.

Harran, Marilyn J. 1997. Martin Luther: Learning for Life. St. Louis (MO): Concordia Publishing House.

Heylen, Freddy and Lorenzo Pozzi. 2007. "Crises and Human Capital Accumulation." Canadian Journal of Economics 40(4): 1261-1285.

Ho, Ping-Ti. 1959. "Aspects of Social Mobility in China, 1368-1911." Comparative Studies in Society and History 1(4): 330-359. 
Holborn, Hajo. 1959. A History of Modern Germany: The Reformation. New York: Knopf. Hsu, Becky, Amy Reynolds, Conrad Hackett and James Gibbon. 2008. "Estimating the Religious Composition of All Nations: An Empirical Assessment of the World Christian Database." Journal for the Scientific Study of Religion 47(4): 678-693.

Hungerman, Daniel M. 2014. "The Effect of Education on Religion: Evidence from Compulsory Schooling Laws." Journal of Economic Behavior and Organization 104: 52-63. Ibrahim, Ali S. 2011. "Education in the United Arab Emirates: A Socio-cultural Analysis." Pp. 327-344 in Handbook of Asian Education: A Cultural Perspective, edited by Yong Zhao, Jing Lei, Guofang Li, Ming Fang He, Kaori Okano, Nagwa Megahed, David Gamage and Hema Ramanathan. New York: Routledge.

IMF. 2014. "World Economic Outlook Database, April 2014 Edition." Available at http:// www.imf.org, accessed 9 May 2014.

Iram, Ya'acov. 1993. "Judaism, Education and National Identity." Pp. 54-71 in World Religions and Educational Practice, edited by Witold Tulasiewicz and Cho-Yee To. London: Cassell.

Jawad, Haifaa A. 1998. The Rights of Women in Islam: An Authentic Approach. Basingstoke: Macmillan.

Johnson, William H. E. 1969. Russia's Educational Heritage. New York: Octagon.

Kalemli-Ozcan, Sebnem, Harl E. Ryder and David N. Weil. 2000. "Mortality Decline, Human Capital Investment, and Economic Growth." Journal of Development Economics 62(1): 1-23.

Karamouzis, Polikarpos. 2015. "Religious Capital in Relation to Teachers' Views of RE. A Comparative Study in the Greek Educational Context." British Journal of Religious Education 37(2): 170-181.

Kelleher, Theresa. 1987. "Confucianism." Pp. 135-16o in Women in World Religions, edited by Arvind Sharma. Albany (NY): State University of New York Press.

Keysar, Ariela and Barry A. Kosmin. 1995. "The Impact of Religious Identification on Differences in Educational Attainment among American Women in 1990." Journal for the Scientific Study of Religion 34(1): 49-62.

King, Ursula. 1987. "World Religions, Women and Education." Comparative Education 23(1): $35^{-49}$.

Kingdon, Geeta Gandhi. 2002. "The Gender Gap in Educational Attainment in India: How Much Can Be Explained?" Journal of Development Studies 39(2): 25-53.

Kingdon, Geeta Gandhi. 2007. "The Progress of School Education in India." Working Paper GPRG-WPS-071, University of Oxford, Oxford.

Koukounaras Liagkis, Marios. 2015. "Religious Education in Greece: A New Curriculum, an Old Issue." British Journal of Religious Education 37(2): 153-169.

Kuipers, Joel C. 2011. "The Society and Its Environment." Pp. 95-162 in Indonesia: A Country Study, 6th ed., edited by William H. Frederick and Robert L. Worden. Washington, D.C.: Library of Congress. 
Laeven, Luc and Fabian Valencia. 2013. "Systemic Banking Crises Database." IMF Economic Review 61(2): 225-270.

Lake, David A. and Matthew A. Baum. 2001. "The Invisible Hand of Democracy: Political Control and the Provision of Public Services." Comparative Political Studies $34(6): 587-621$.

Lee, Thomas H. C. 2000. Education in Traditional China: A History. Leiden: Brill.

Lehrer, Evelyn L. 1999. "Religion as a Determinant of Educational Attainment: An Economic Perspective." Social Science Research 28(4): 358-379.

Lehrer, Evelyn L. 2006. "Religion and High-School Graduation: A Comparative Analysis of Patterns for White and Black Young Women." Review of Economics of the Household 4(3): 277-293.

Lehrer, Evelyn L. 2010. "Religious Affiliation and Participation as Determinants of Women's Educational Attainment and Wages." Pp. 186-205 in Religion, Families and Health: Population-Based Research in the United States, edited by Christopher G. Ellison and Robert A. Hummer. New Brunswick (NJ): Rutgers University Press.

Lenard, Max. 2006. "On the Origin, Development and Demise of the Index Librorum Prohibitorum." Journal of Access Services 3(4): 51-63.

Lewis, Bernard. 2002. The Emergence of Modern Turkey, 3rd ed. New York: Oxford University Press.

Ling, Trevor. 1976. The Buddha: Buddhist Civilization in India and Ceylon. Middlesex: Penguin.

Maoz, Zeev and Errol A. Henderson. 2013a. "The World Religion Dataset, Version 1.1." Available at http://www.correlatesofwar.org, accessed 11 February 2014.

Maoz, Zeev and Errol A. Henderson. 2013b. "The World Religion Dataset, 1945-2010: Logic, Estimates, and Trends." International Interactions 39(3): 265-291.

Marshall, Monty G., Ted Robert Gurr and Keith Jaggers. 2014. "Polity IV Project: Political Regime Characteristics and Transitions, 1800-2013, Version 2013." Available at http://www.systemicpeace.org, accessed 4 June 2014.

Marshall, Susan E. 1985. "Development, Dependence, and Gender Inequality in the Third World." International Studies Quarterly 29(2): 217-240.

Massengill, Rebekah Peeples. 2008. "Educational Attainment and Cohort Change among Conservative Protestants, 1972-2004." Journal for the Scientific Study of Religion 47(4): 545-562.

Matthews, Mervyn. 1982. Education in the Soviet Union: Policies and Institutions since Stalin. London: George Allen \& Unwin.

Megahed, Nagwa M. 2011. "A Cultural Overview of Islam and Education." Pp. 319-326 in Handbook of Asian Education: A Cultural Perspective, edited by Yong Zhao, Jing Lei, Guofang Li, Ming Fang He, Kaori Okano, Nagwa Megahed, David Gamage and Hema Ramanathan. New York: Routledge. 
Mehran, Golnar. 1992a. "Iran." Pp. 283-304 in International Handbook of Education Reform, edited by Peter W. Cookson, Alan R. Sadovnik and Susan F. Semel. New York: Greenwood.

Mehran, Golnar. 1992b. "Cultural Revolution and Educational Transformation in the Islamic Republic of Iran." World Education News \& Reviews Winter: 9-18.

Méndez, Fabio and Facundo Sepúlveda. 2012. "The Cyclicality of Skill Acquisition: Evidence from Panel Data." American Economic Journal: Macroeconomics 4(3): 128-152.

Miller, Helena, Lisa D. Grant and Alex Pomson. 2011. "Introduction." Pp. 1-5 in International Handbook of Jewish Education, Part 1, edited by Helena Miller, Lisa D. Grant and Alex Pomson. Dordrecht: Springer.

Mincer, Jacob. 1996. "Economic Development, Growth of Human Capital, and the Dynamics of the Wage Structure." Journal of Economic Growth 1(1): 29-48.

Mitchell, Peter. 1993. "Protestantism and Educational Provision." Pp. 125-143 in World Religions and Educational Practice, edited by Witold Tulasiewicz and Cho-Yee To. London: Cassell.

Mocan, Naci and Luiza Pogorelova. 2014. "Compulsory Schooling Laws and Formation of Beliefs: Education, Religion and Superstition.” NBER Working Paper No. 20557, NBER, Cambridge (MA).

Mukhopadhyay, Sankar. 2011. "Religion, Religiosity and Educational Attainment of Immigrants to the USA." Review of Economics of the Household 9(4): 539-553.

Nakosteen, Mehdi. 1964. History of Islamic Origins of Western Education, A.D. 800-1350. Boulder (CO): University of Colorado Press.

Neal, Derek. 1997. "The Effects of Catholic Secondary Schooling on Educational Achievement." Journal of Labor Economics 15(1, 1): 98-123.

Norton, Seth W. and Annette Tomal. 2009. "Religion and Female Educational Attainment." Journal of Money, Credit and Banking 41(5): 961-986.

O'Malley, John W. 2014. The Jesuits: A History from Ignatius to the Present. Lanham (MD): Rowman \& Littlefield.

Ornstein, Allan C., Daniel U. Levine, Gerald L. Gutek and David E. Vocke. 2013. Foundations of Education, 12th ed. Belmont (CA): Wadsworth.

Papagapitos, Agapitos and Robert Riley. 2009. "Social Trust and Human Capital Formation." Economics Letters 102(3): 158-160.

Parajuli, Deepak Raj and Tapash Das. 2013. "Performance of Community Schools in Nepal: A Macro Level Analysis." International Journal of Scientific and Technology Research 2(7): 148-154.

Paulsen, Friedrich. 1908. German Education: Past and Present. London: Fisher Unwin.

Pew Research Center. 2011. Global Christianity: A Report on the Size and Distribution of the World's Christian Population. Washington, D.C.: Pew Research Center. 
Pew Research Center. 2012. The Global Religious Landscape: A Report on the Size and Distribution of the World's Major Religious Groups as of 2010. Washington, D.C.: Pew Research Center.

Ranjan, Priya. 2001. "Dynamic Evolution of Income Distribution and Credit-Constrained Human Capital Investment in Open Economies." Journal of International Economics 55(2): 329-358.

Richters, Katja. 2013. The Post-Soviet Russian Orthodox Church: Politics, Culture and Greater Russia. Abingdon: Routledge.

Robinson, David W. 2012. "Notes on Protestant Education in England." Pp. 225-244 in International Handbook of Protestant Education, edited by William Jeynes and David W. Robinson. Heidelberg: Springer.

Roodman, David. 2009a. "A Note on the Theme of Too Many Instruments." Oxford Bulletin of Economics and Statistics 71(1): 135-158.

Roodman, David. 20ogb. "How to Do xtabond2: An Introduction to Difference and System GMM in Stata." Stata Journal 9(1): 86-136.

Rudra, Nita and Stephan Haggard. 2005. "Globalization, Democracy, and Effective Welfare Spending in the Developing World." Comparative Political Studies 38(9): $1015^{-1049 .}$

Samten, Geshe Ngawang. 2009. "A Buddhist Perspective on the Agenda for Education in a Postmodern World." Available at https://dharmadana.wordpress.com, accessed 20 August 2015 .

Sander, William. 1992. "The Effects of Ethnicity and Religion on Educational Attainment." Economics of Education Review 11(2): 119-135.

Sander, William. 2010. "Religious Background and Educational Attainment: The Effects of Buddhism, Islam, and Judaism." Economics of Education Review 29(3): 489-493.

Sebaly, Kim P. 1993. "Provision for Hinduism in Modern Education." Pp. 33-53 in World Religions and Educational Practice, edited by Witold Tulasiewicz and Cho-Yee To. London: Cassell.

Shamsavary, Parisima, Ghulam Nabi Saqeb and Mark Halstead. 1993. "Islam: State, Religion and Education." Pp. 144-160 in World Religions and Educational Practice, edited by Witold Tulasiewicz and Cho-Yee To. London: Cassell.

Sherkat, Darren E. 2011. "Religion and Scientific Literacy in the United States." Social Science Quarterly 92(5): 1134-1150.

Sheshagiri, K. M. 2011. "A Cultural Overview of Education in Hindu Civilization." Pp. 463-480 in Handbook of Asian Education: A Cultural Perspective, edited by Yong Zhao, Jing Lei, Guofang Li, Ming Fang He, Kaori Okano, Nagwa Megahed, David Gamage and Hema Ramanathan. New York: Routledge.

Singh, Yogesh Kumar and Ruchika Nath. 2005. History of Indian Education System. New Delhi: APH Publishing Corporation. 
Skidmore, Mark and Hideki Toya. 2002. "Do Natural Disasters Promote Long-Run Growth?" Economic Inquiry 40(4): 664-687.

Smith, Jane I. 1987. "Islam." Pp. 235-250 in Women in World Religions, edited by Arvind Sharma. Albany (NY): State University of New York Press.

Soares, Rodrigo R. 2005. "Mortality Reductions, Educational Attainment, and Fertility Choice." American Economic Review 95(3): 580-601.

Starr, Don. 2012. "China and the Confucian Education Model." Available at http://www .universitas21.com, accessed 4 September 2015.

Strauss, Gerald. 1978. Luther's House of Learning: Indoctrination of the Young in the German Reformation. Baltimore (MD): John Hopkins University Press.

Sun, Anna. 2013. Confucianism as a World Religion: Contested Histories and Contemporary Realities. Princeton (NJ): Princeton University Press.

Sun-keung Pang, Nicholas. 2011. "Educational Governance and Management in Sinic Societies." Pp. 7-28 in Handbook of Asian Education: A Cultural Perspective, edited by Yong Zhao, Jing Lei, Guofang Li, Ming Fang He, Kaori Okano, Nagwa Megahed, David Gamage and Hema Ramanathan. New York: Routledge.

Swarup, Ram. 2000 [1971]. "The Hindu View of Education." In On Hinduism: Reviews and Reflections, by Ram Swarup. Available at http://voiceofdharma.org, accessed 21 August 2015 .

To, Cho-Yee. 1993. "Confucianism in East Asia." Pp. 72-83 in World Religions and Educational Practice, edited by Witold Tulasiewicz and Cho-Yee To. London: Cassell.

Tulasiewicz, Witold. 1993. "Eastern Orthodoxy: Doctrine, Learning, Nationality and the State." Pp. 104-124 in World Religions and Educational Practice, edited by Witold Tulasiewicz and Cho-Yee To. London: Cassell.

UNESCO Institute for Statistics. 2015. "Education Statistics." Available at http://www .uis.unesco.org, accessed 2 September 2015.

V, Jayaram. 2015. "Hinduism and Education." Available at http://www.hinduwebsite .com, accessed 20 August 2015.

Vella, Francis. 1999. "Do Catholic Schools Make a Difference? Evidence from Australia." Journal of Human Resources 34(1): 208-224.

Vrame, Anton C. 1999. The Educating Icon: Teaching Wisdom and Holiness in the Orthodox Way. Brookline (MA): Holy Cross Orthodox Press.

Vrame, Anton C. 2006. "An Overview of Orthodox Christian Religious Education." Pp. 277-292 in International Handbook of the Religious, Moral and Spiritual Dimensions in Education, Part 1, edited by Marian de Souza, Gloria Durka, Kathleen Engebretson and Robert Jackson. Dordrecht: Springer.

Ware, Timothy. 2015. The Orthodox Church: An Introduction to Eastern Christianity, 3rd ed. London: Penguin.

Williamson, Bill. 1987. Education and Social Change in Egypt and Turkey: A Study in Historical Sociology. Basingstoke: Macmillan. 
World Bank. 2014. "World Development Indicators." Available at http://data.worldbank.org, accessed 6 June 2014.

Yang, Huanyin. 1993. "Confucius (K'ung Tzu) (551-479 вС)." Prospects: Quarterly Review of Comparative Education 23(1-2): 211-219.

Yung, Dong. 2003. "Buddhism: Education for a Modern World." Hsi Lai Journal of Humanistic Buddhism 4: 284-293.

Zeldin, Michael. 2011. "Preface." Pp. v-viii in International Handbook of Jewish Education, Part 1, edited by Helena Miller, Lisa D. Grant and Alex Pomson. Dordrecht: Springer. 


\section{Appendices}

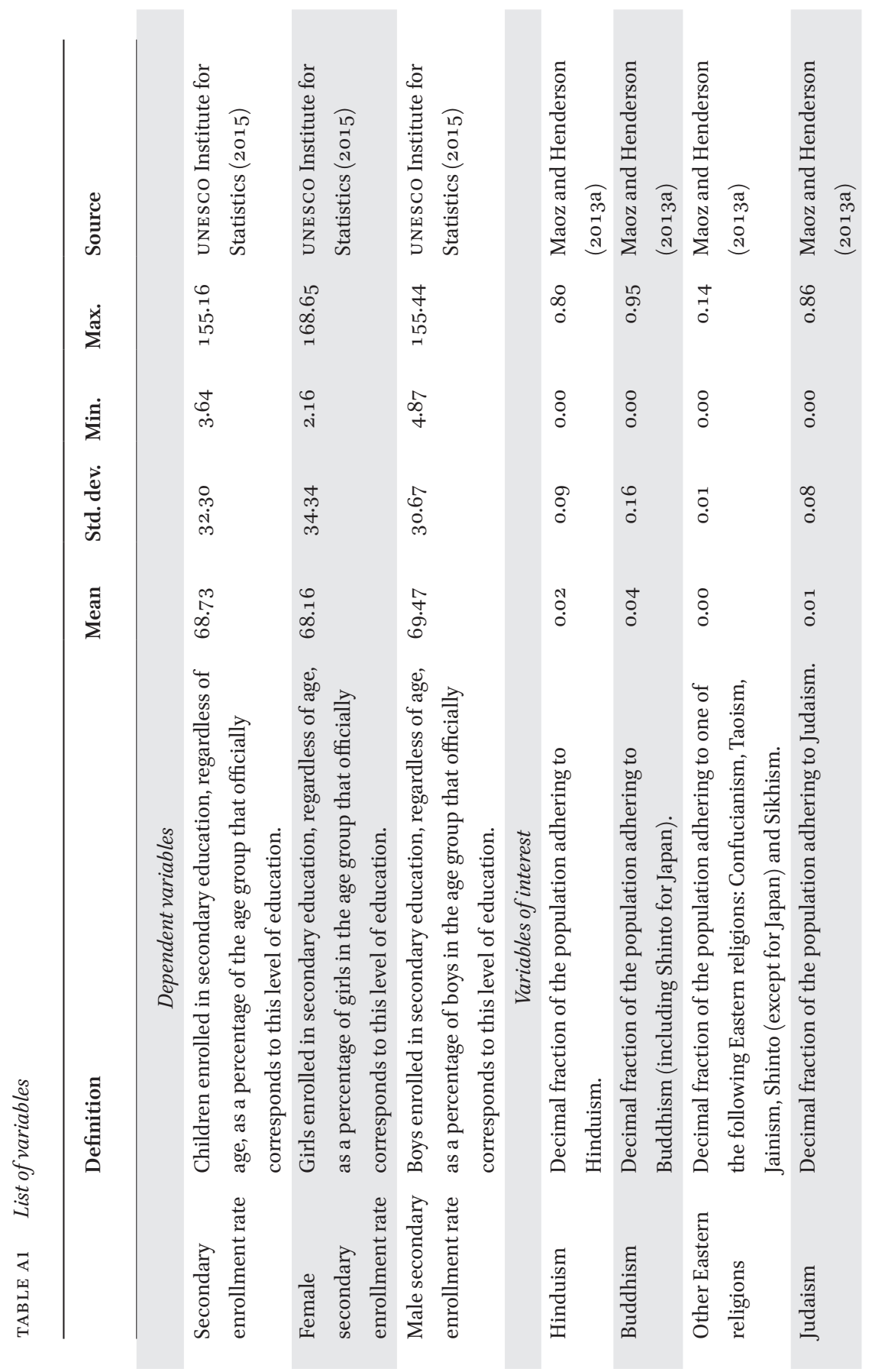




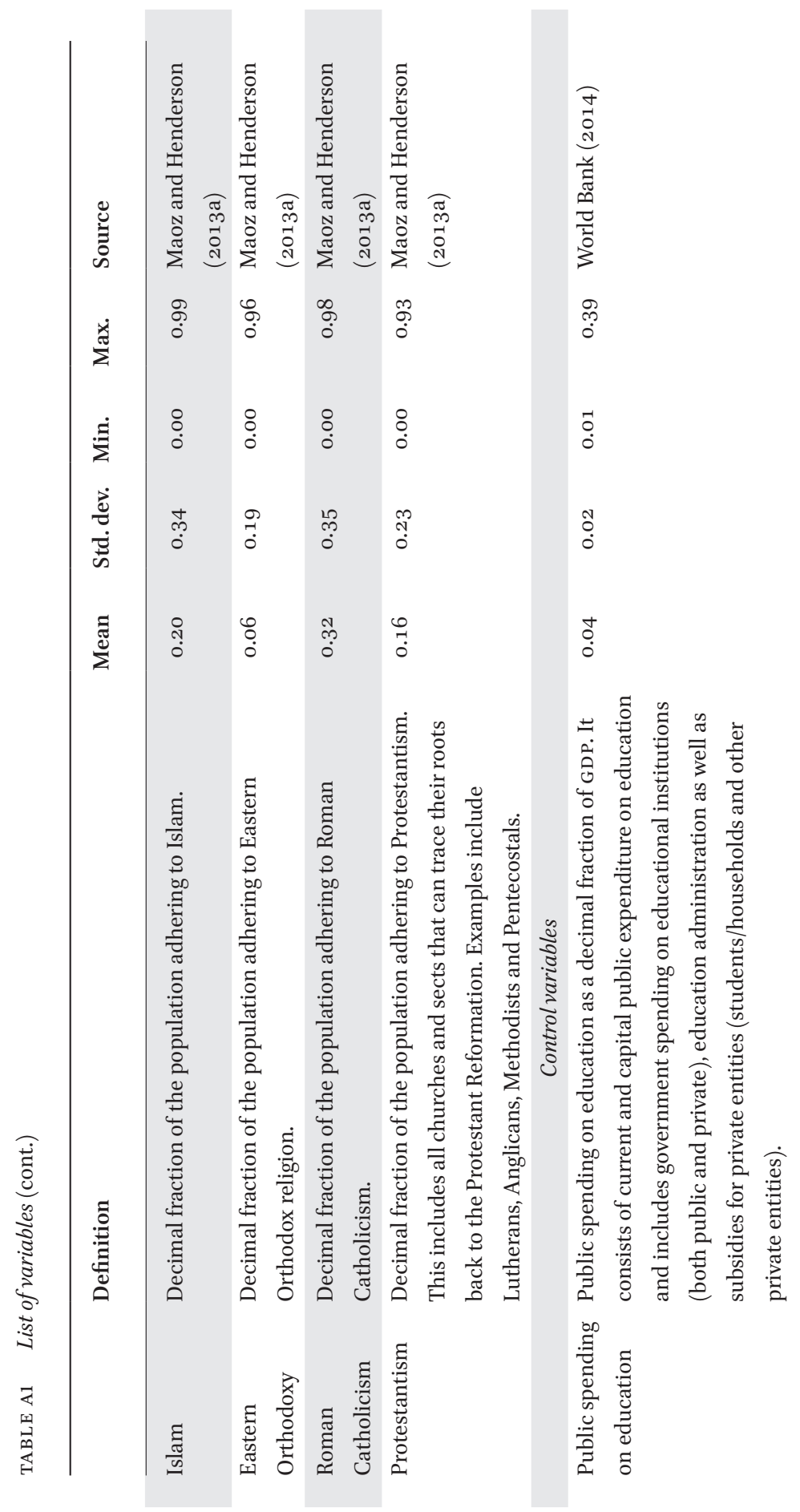




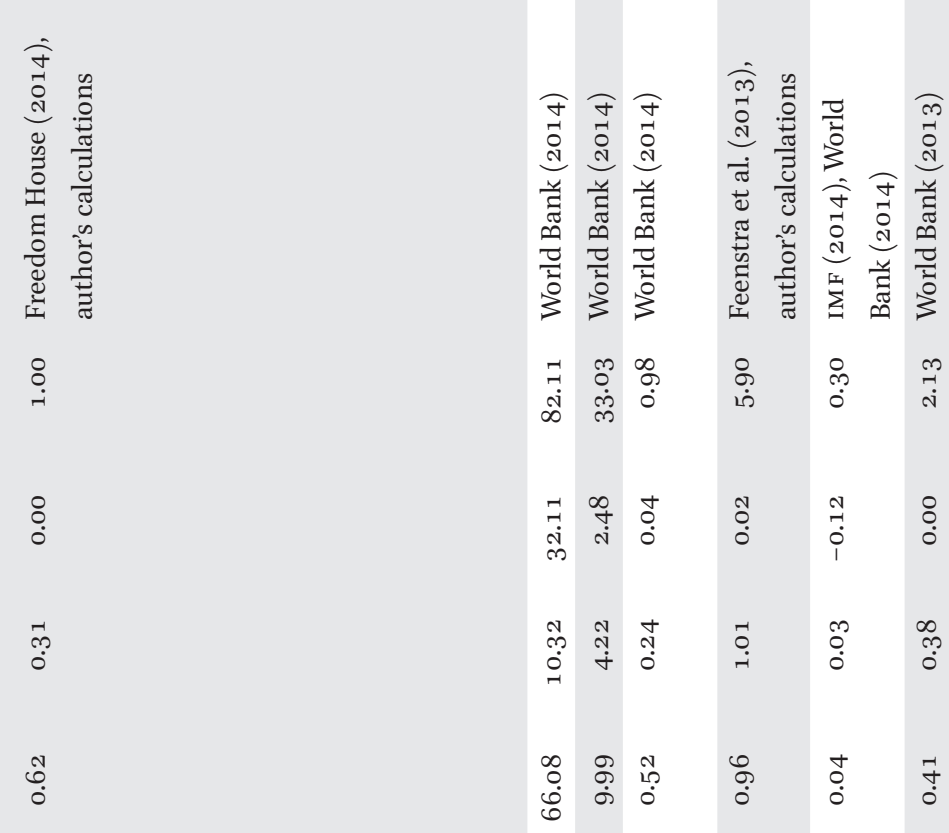

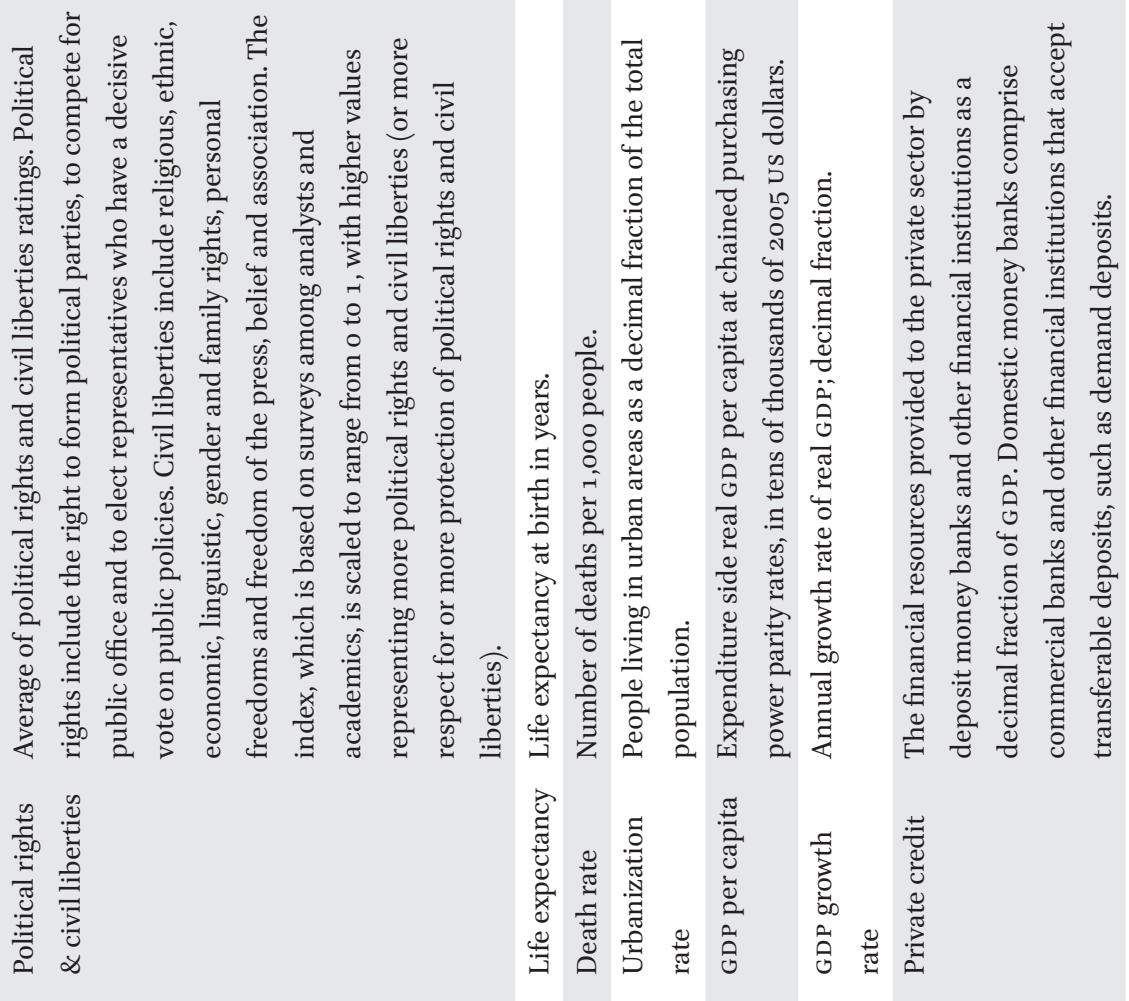




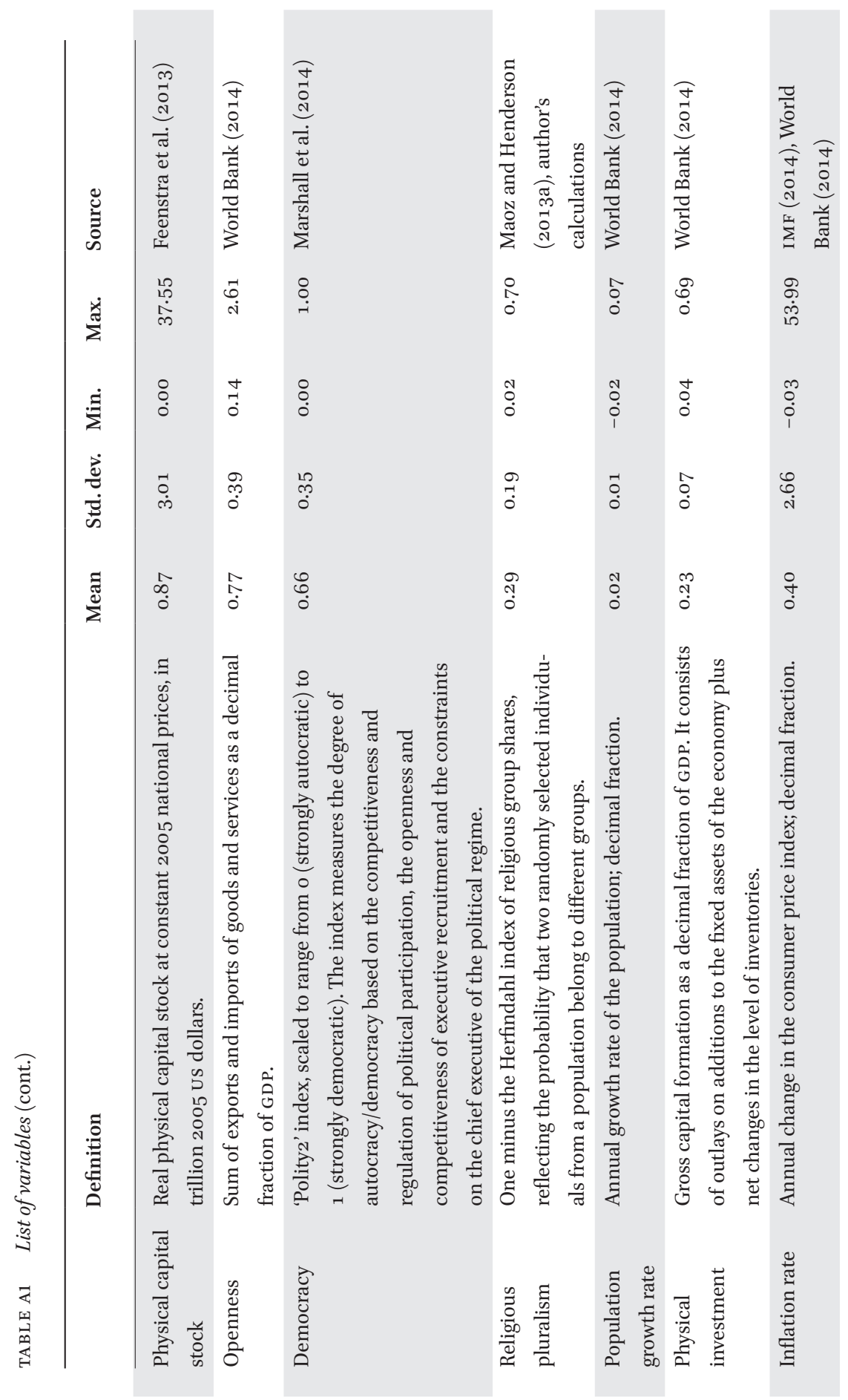


0
0
0
0
0
0
0
0
0
0
0
0
0
0
0
0
0
0
0
0
0
0
0
0
0

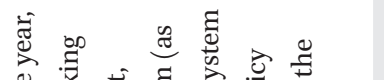

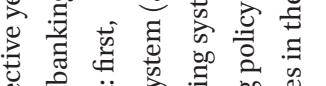

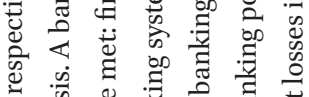

Е

声

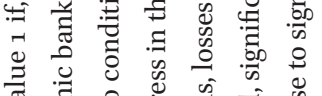

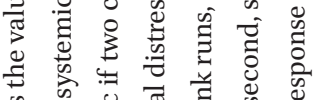

焉

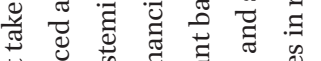

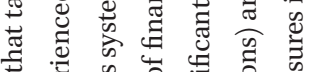

I

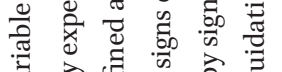

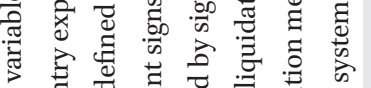

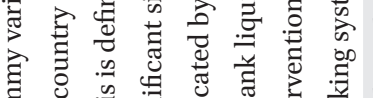

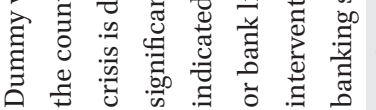

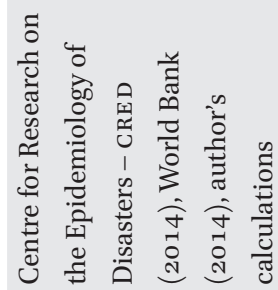

กิ

$\stackrel{8}{\circ}$

$\stackrel{\infty}{0}$

$\ddot{0}$

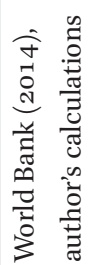

$\stackrel{?}{\circ}$

$\stackrel{\circ}{\circ}$

$\stackrel{0}{\circ}$

$\stackrel{5}{0}$

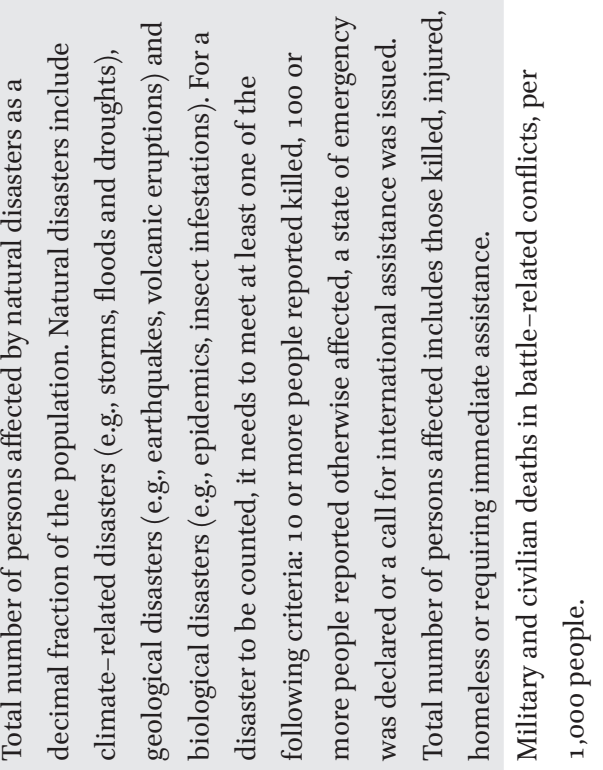

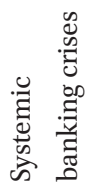

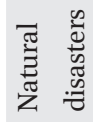

$\stackrel{\infty}{3}$ 


\section{List of Countries}

Albania, Angola, Antigua and Barbuda, Argentina, Armenia, Australia, Austria, Azerbaijan, Bahamas, Bahrain, Bangladesh, Barbados, Belarus, Belgium, Belize, Benin, Bhutan, Bolivia, Botswana, Brunei Darussalam, Bulgaria, Burkina Faso, Burundi, Cabo Verde, Cambodia, Cameroon, Canada, Central African Republic, Chad, China, Colombia, Comoros, Costa Rica, Côte d'Ivoire, Croatia, Cyprus, Czech Republic, Democratic Republic of the Congo, Denmark, Djibouti, Dominica, Dominican Republic, Ecuador, Egypt, El Salvador, Equatorial Guinea, Estonia, Ethiopia, Fiji, Finland, France, Gabon, Gambia, Georgia, Germany, Ghana, Greece, Grenada, Guatemala, Guinea, Guinea Bissau, Honduras, Hungary, Iceland, India, Indonesia, Iran, Ireland, Israel, Italy, Jamaica, Japan, Jordan, Kazakhstan, Kenya, Kuwait, Kyrgyzstan, Laos, Latvia, Lesotho, Lithuania, Luxembourg, Macedonia, Madagascar, Malawi, Malaysia, Mali, Malta, Mauritania, Mauritius, Mexico, Moldova, Mongolia, Morocco, Mozambique, Namibia, Nepal, Netherlands, New Zealand, Niger, Nigeria, Norway, Oman, Pakistan, Panama, Paraguay, Peru, Philippines, Poland, Portugal, Republic of the Congo, Romania, Russia, Rwanda, Saint Kitts and Nevis, Saint Lucia, Saint Vincent and the Grenadines, Saudi Arabia, Senegal, Slovakia, Slovenia, South Africa, South Korea, Spain, Sri Lanka, Swaziland, Sweden, Switzerland, Syria, Tajikistan, Tanzania, Thailand, Togo, Trinidad and Tobago, Tunisia, Turkey, Uganda, Ukraine, United Kingdom, United States, Uruguay, Zambia, Zimbabwe. 